\title{
42. GEOCHEMISTRY OF RARE EARTHS AND OTHER TRACE ELEMENTS IN SEDIMENTS FROM SITES 798 AND 799, JAPAN SEA ${ }^{1}$
}

\author{
Yoshitaka Minai, ${ }^{2}$ Ryo Matsumoto, ${ }^{3}$ Yoshio Watanabe, ${ }^{4}$ and Takeshi Tominaga ${ }^{2}$
}

\begin{abstract}
Nineteen trace elements, including seven rare earth elements (REE's), and 10 major and minor elements in 76 sediment samples from Sites 798 (Oki Ridge) and 799 (Yamato Trough) were determined by means of instrumental neutron activation analysis and X-ray fluorescence spectrometry. Most REE patterns (chondrite-normalized) of the sediments from both sites were nearly identical to the patterns of terrigenous materials. The cerium anomaly (slightly positive) frequently appeared in REE patterns of the sediments (200-750 mbsf) from Site 799. Cerium may be selectively incorporated into the sediments with hydrogenous manganese precipitation. However, the degree of the anomaly was not well correlated with manganese content, suggesting that cerium may behave as a trivalent REE (like the other REE's) during diagenesis while manganese is transported in the sediment column accompanied by reduction to a lower oxidation state. The Th/Sc ratio of the sediments from Sites 798 and 799 tended to decrease with penetration depth. Such a depth profile may indicate a decrease in basic volcanism activities from the Pliocene (Site 798) and Miocene (Site 799). The $\mathrm{La} / \mathrm{Yb}$ ratio and degree of europium anomaly also varied with depth, which may imply that two or more components with different REE patterns were supplied throughout sedimentation at sites in the Japan Sea.
\end{abstract}

\section{INTRODUCTION}

The geology and geophysics of the Japan Sea have been extensively studied over the past two decades as a typical backarc basin system. However, the geological history of the Japan Sea system is still controversial. From Sites 798 (Oki Ridge) and 799 (Yamato Trough) of Leg 128 (Fig. 1), 590-m and 1084-m long sediment cores were recovered. These cores provide information on changes of sedimentation environments from the Pliocene (Site 798) or early Miocene (Site 799) to the Holocene. In this article, we report the geochemistry of major, minor, and trace elements, including seven rare earth elements (REE's), in sediments from the Japan Sea, based on the analysis of 76 sediments from Sites 798 and 799. The geochemistry of REE and other trace elements has provided useful information for estimating the origin and formation processes of marine sediments (e.g., Bender et al., 1971; Matsumoto et al., 1985; Minai and Tominaga, 1989; McLennan et al., 1990; Toyoda and Masuda, 1990; Toyoda et al., 1990).

We have studied the geochemistry of REE's and other trace elements in deep sea sediments collected from the Pacific (Minai, 1982; Minai and Tominaga, 1989) and from DSDP sites at the Nankai Trough, the Japan Trench, and adjacent regions (Minai et al., 1985). Previously, a model for classification of oceanic sediment was proposed (Matsumoto et al., 1985) based on concentrations of the REE's reported in the literature (including our studies mentioned above). On the basis of this review we have proposed that selective depletion of cerium in the REE pattern (negative cerium anomaly) of oceanic sediments can be regarded as a measure of hydrothermal activity. As reported previously (Minai et al., 1985), such an anomaly was observed in the REE patterns of pelagic sediment from Site 294 (western Philippine Basin) and of sedimentary rocks near the basements at

'Pisciotto, K. A., Ingle, J. C., Jr., von Breymann, M. T., Barron, J., et al., 1992. Proc. ODP, Sci. Results, 127/128, Pt. 1: College Station, TX (Ocean Drilling Program).

${ }^{2}$ Department of Chemistry, Faculty of Science, University of Tokyo, Hongo, Tokyo 113, Japan. Japan.

Geological Institute, Faculty of Science, University of Tokyo, Hongo, Tokyo 113,

\footnotetext{
${ }^{4}$ Geological Survey of Japan, Tsukuba, Ibaraki 305, Japan.
}

Sites 296 (the Shikoku Basin) and 436 (the Japan Trench). One of our objectives in this article was to investigate traces of hydrothermal activities in the sediment columns from the Japan Sea, based on the geochemistry of REE's and other trace elements.

The primary objective of this work is to elucidate the sedimentation history of the Japan Sea. It has been claimed that Japan Sea sedimentation was mainly controlled by both volcanic activities (accompanied by hydrothermal activities) and rapid influx of terrigenous materials derived from the continent and the Japanese Islands (Karig, Ingle, et al., 1975; Tamaki, 1988). In addition, it is probable that the opening of the Japan Sea was caused by complicated processes of rifting and spreading of centers at various ages. As shown in our studies on sediments from various regions around the Japanese Islands (Minai et al., 1985), concentrations of REE's and other trace elements and their relative correlations are extremely useful for elucidating the origin of terrigenous materials in the sediments. It can be expected that detailed studies of REE patterns and their relations to the abundances of other elements in sediments may provide clues to elucidating the complex history of sedimentation processes in the Japan Sea.

\section{EXPERIMENTAL}

For each sample, a few grams of sediment were washed with deionized water to remove water-soluble species (e.g., $\mathrm{NaCl}$ ) in the sediment columns before being dried in an oven at $50^{\circ} \mathrm{C}$. The air-dried samples were finely pulverized for X-ray fluorescence analysis (XRF) and instrumental neutron activation analysis (INAA).

Five hundred milligrams of the pulverized sample were ignited at $600^{\circ} \mathrm{C}$ to determine loss on ignition (LOI). After the determination of LOI, the powders were fused with anhydrous lithium borate to prepare a bead sample for XRF. The analysis was carried out with a Phillips IW-1400 XRF spectrometer. Ten major and minor elements ( $\mathrm{Si}, \mathrm{Ti}$, $\mathrm{Al}, \mathrm{Fe}, \mathrm{Mn}, \mathrm{Mg}, \mathrm{Ca}, \mathrm{Na}, \mathrm{K}$, and $\mathrm{P}$ ) were determined with correction of LOI, applying calibration curves prepared by analysis of various standard rocks.

One hundred milligrams of the pulverized sample was taken for INAA. The portion was sealed in polyethylene film for neutron irradiation. Ten to twenty samples together with standard rocks (JB-1 and JLk-1 issued by the Geological Survey of Japan), whose recommended values of the elemental concentrations were presented in 


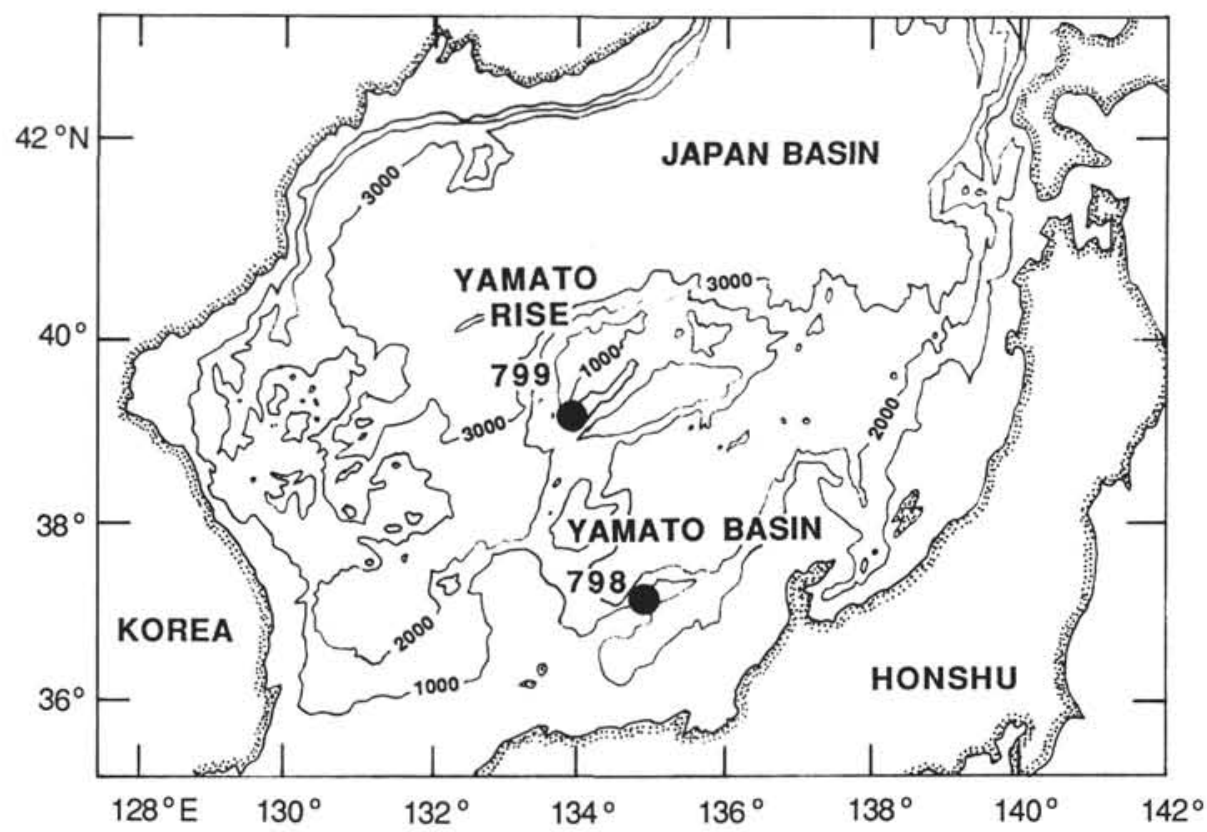

Figure 1. Locations of Sites 798 and 799, Leg 128.

Ando et al. (1989) and Ebihara et al. (1985), were irradiated for 18-24 hr with $5 \times 1011 \mathrm{~cm}^{-2} \mathrm{~s}^{-1}$ thermal neutron flux in a TRIGA-II nuclear reactor at Rikkyo University. Iron wires were applied for monitoring neutron flux at the sample positions. For 5-7 days after the end of irradiation, $\mathrm{As}, \mathrm{Ba}, \mathrm{Br}, \mathrm{U}, \mathrm{La}, \mathrm{Sm}$, and $\mathrm{Lu}$ concentrations were determined by means of gamma-ray spectrometry, using an intrinsic germanium semiconductor detector (Laboratory for Earthquake Chemistry, University of Tokyo) or a lithium-drifted germanium semiconductor detector (Radioisotope Center, University of Tokyo). Also, for 20-40 days after the end of irradiation $\mathrm{Co}, \mathrm{Cr}, \mathrm{Cs}, \mathrm{Hf}, \mathrm{Sb}, \mathrm{Sc}, \mathrm{Ta}, \mathrm{Th}, \mathrm{Ce}, \mathrm{Eu}$, $\mathrm{Tb}$, and $\mathrm{Yb}$ concentrations were determined by the same method. Analytical precisions estimated from the counting statistics for Sample 128-799A-3H-4, $41-43 \mathrm{~cm}$, as an example, are as follows: As (11\%), $\mathrm{Ba}(17 \%), \mathrm{Br}(15 \%), \mathrm{Co}(1 \%), \mathrm{Cr}(2 \%), \mathrm{Cs}(9 \%), \mathrm{Hf}(4 \%), \mathrm{Sb}(7 \%)$, Sc $(0.3 \%)$, Ta (5\%), Th (1\%), U (11\%), La (1\%), Ce (1\%), Sm (1\%), $\mathrm{Eu}(3 \%), \mathrm{Tb}(15 \%), \mathrm{Yb}(7 \%)$, and $\mathrm{Lu}(9 \%)$.

\section{RESULTS}

\section{Site 798}

Site 798 (Fig. 1) is located at a small basin on the top of Oki Ridge (Hole $798 \mathrm{~B}: 37^{\circ} 03.848^{\prime} \mathrm{N}, 134^{\circ} 79.961^{\prime} \mathrm{E}$ ). A 517.9-m long sediment core of late early Pliocene to Holocene sediment was recovered from Hole $798 \mathrm{~B}$ at this site, where the water depth was $911.1 \mathrm{~m}$. At an average sedimentation rate of about $120 \mathrm{~m} / \mathrm{m}$.y. the pelagic-hemipelagic sediments were deposited above the carbonate compensation depth (Ingle, Suyehiro, von Breymann, et al., 1990). The sediment column was divided into three lithological units: Unit I (0-220 mbsf, latest Quaternary to latest Pliocene), Unit II (220-455 mbsf, late Pliocene), and Unit III (455-518 mbsf, late to late early Pliocene) (Ingle, Suyehiro, von Breymann, et al., 1990).

Analytical XRF and INAA results are listed in Table 1 (for major and minor elements) and Table 2 (for trace elements). Depth profiles

Table 1. Major and minor element contents in the sediments from Site 798.

\begin{tabular}{|c|c|c|c|c|c|c|c|c|c|c|c|c|c|}
\hline $\begin{array}{c}\text { Sample } \\
\text { no. }\end{array}$ & $\begin{array}{l}\text { Core, section, } \\
\text { interval }(\mathrm{cm})\end{array}$ & $\begin{array}{l}\text { Depth } \\
\text { (mbsf) }\end{array}$ & $\begin{array}{l}\mathrm{SiO}_{2} \\
(\%)\end{array}$ & $\begin{array}{l}\mathrm{TiO}_{2} \\
(\%)\end{array}$ & $\begin{array}{l}\mathrm{Al}_{2} \mathrm{O}_{3} \\
(\%)\end{array}$ & $\begin{array}{c}\mathrm{Fe}_{2} \mathrm{O}_{3}{ }^{\mathrm{a}} \\
(\%)\end{array}$ & $\begin{array}{c}\mathrm{MnO} \\
(\%)\end{array}$ & $\begin{array}{l}\mathrm{MgO} \\
(\%)\end{array}$ & $\begin{array}{l}\mathrm{CaO} \\
(\%)\end{array}$ & $\begin{array}{c}\mathrm{Na}_{2} \mathrm{O} \\
(\%)\end{array}$ & $\begin{array}{l}\mathrm{K}_{2} \mathrm{O} \\
(\%)\end{array}$ & $\begin{array}{r}\mathrm{P}_{2} \mathrm{O}_{5} \\
(\%)\end{array}$ & $\begin{array}{l}\text { LOI } \\
(\%)\end{array}$ \\
\hline 1 & $798 \mathrm{~A}-1 \mathrm{H}-4,86-88$ & 5.36 & 52.96 & 0.62 & 14.28 & 5.33 & 0.053 & 2.30 & 3.49 & 1.42 & 2.53 & 0.142 & 16.89 \\
\hline 2 & 1H-5, 94-96 & 6.94 & 48.54 & 0.53 & 13.00 & 4.97 & 0.052 & 2.33 & 10.63 & 1.11 & 2.33 & 0.137 & 16.38 \\
\hline 3 & $5 \mathrm{H}-2,86-88$ & 39.06 & 38.86 & 0.42 & 11.48 & 4.41 & 0.038 & 1.81 & 18.69 & 1.05 & 1.58 & 0.136 & 21.54 \\
\hline 4 & $5 \mathrm{H}-3,85-82$ & 40.55 & 56.17 & 0.58 & 14.42 & 4.77 & 0.046 & 1.76 & 2.17 & 1.53 & 2.52 & 0.119 & 15.92 \\
\hline 5 & $11 \mathrm{H}-2,97-99$ & 96.57 & 56.64 & 0.59 & 14.25 & 4.83 & 0.036 & 1.70 & 0.97 & 1.13 & 2.34 & 0.116 & 17.38 \\
\hline 6 & $11 \mathrm{H}-3,90-92$ & 98.00 & 47.16 & 0.52 & 13.63 & 5.39 & 0.057 & 1.96 & 11.97 & 0.98 & 2.30 & 0.149 & 15.88 \\
\hline 7 & $798 \mathrm{~B}-14 \mathrm{H}-4,92-94$ & 127.51 & 54.42 & 0.51 & 12.20 & 4.72 & 0.038 & 1.70 & 8.22 & 1.18 & 2.11 & 0.143 & 14.76 \\
\hline 8 & $18 X-2,90-92$ & 164.30 & 59.76 & 0.56 & 13.10 & 4.72 & 0.041 & 1.85 & 4.95 & 1.11 & 2.31 & 0.119 & 11.48 \\
\hline 9 & $21 X-4,98-100$ & 195.79 & 64.27 & 0.64 & 13.90 & 4.97 & 0.040 & 1.70 & 0.99 & 1.13 & 2.66 & 0.101 & 9.62 \\
\hline 10 & $25 X-1,95-97$ & 230.65 & 64.84 & 0.49 & 13.18 & 4.83 & 0.042 & 1.61 & 0.65 & 1.29 & 2.65 & 0.101 & 10.22 \\
\hline 11 & $30 \times-3,90-92$ & 281.10 & 56.83 & 0.65 & 15.40 & 6.85 & 0.044 & 2.13 & 0.98 & 1.04 & 3.02 & 0.115 & 12.93 \\
\hline 12 & $33 \mathrm{X}-2,90-92$ & 308.10 & 67.87 & 0.43 & 10.71 & 3.82 & 0.026 & 1.12 & 0.28 & 0.95 & 2.02 & 0.070 & 12.71 \\
\hline 13 & $37 \mathrm{X}-3,10-12$ & 347.30 & 58.67 & 0.68 & 16.36 & 6.43 & 0.036 & 1.97 & 0.58 & 0.84 & 2.96 & 0.089 & 11.38 \\
\hline 14 & $40 X-4,123-125$ & 378.93 & 62.28 & 0.57 & 14.07 & 5.12 & 0.026 & 1.63 & 0.38 & 0.89 & 2.36 & 0.088 & 12.59 \\
\hline 15 & $43 X-5,90-92$ & 409.10 & & & & & & & & & & & 13.87 \\
\hline 16 & $47 X-6,30-32$ & 447.43 & 63.57 & 0.55 & 13.28 & 5.11 & 0.021 & 1.46 & 0.42 & 1.04 & 2.25 & 0.072 & 12.23 \\
\hline 17 & $49 X-6,88-90$ & 468.48 & 61.19 & 0.70 & 15.97 & 5.93 & 0.043 & 2.07 & 0.62 & 1.12 & 2.96 & 0.083 & 9.31 \\
\hline 18 & $51 X-5,90-92$ & 486.30 & 64.70 & 0.60 & 13.51 & 4.97 & 0.036 & 1.82 & 0.67 & 0.90 & 2.39 & 0.091 & 10.32 \\
\hline 19 & $52 X-2,88-90$ & 491.38 & 60.24 & 0.73 & 15.65 & 5.89 & 0.041 & 2.04 & 0.76 & 1.18 & 2.84 & 0.082 & 10.55 \\
\hline 20 & $53 X-5,42-44$ & 505.12 & 60.67 & 0.58 & 12.79 & 4.93 & 0.025 & 1.76 & 0.56 & 0.93 & 2.40 & 0.113 & 15.24 \\
\hline
\end{tabular}

${ }^{2}$ Total iron as $\mathrm{Fe}_{2} \mathrm{O}_{3}$. 
of elemental concentrations are shown in Figure 2 (for major and minor elements) and Figure 3 (for trace elements).

\section{Site 799}

Site 799 (Fig. 1) is located in the Kita-Yamato Trough (Hole 799A: $39^{\circ} 2.046^{\prime} \mathrm{N}, 133^{\circ} 86.685^{\prime} \mathrm{E}$; Hole $799 \mathrm{~B}: 39^{\circ} 22.048^{\prime} \mathrm{N}$, $\left.133^{\circ} 86.645^{\prime} \mathrm{E}\right)$. From Holes $799 \mathrm{~A}$ and $799 \mathrm{~B}$, a $1084.0-\mathrm{m}$ long sediment column (early Miocene to Holocene age) was recovered beneath $2073 \mathrm{~m}$ of water (Ingle, Suyehiro, von Breymann, et al., 1990). The sediment column was composed of five lithological
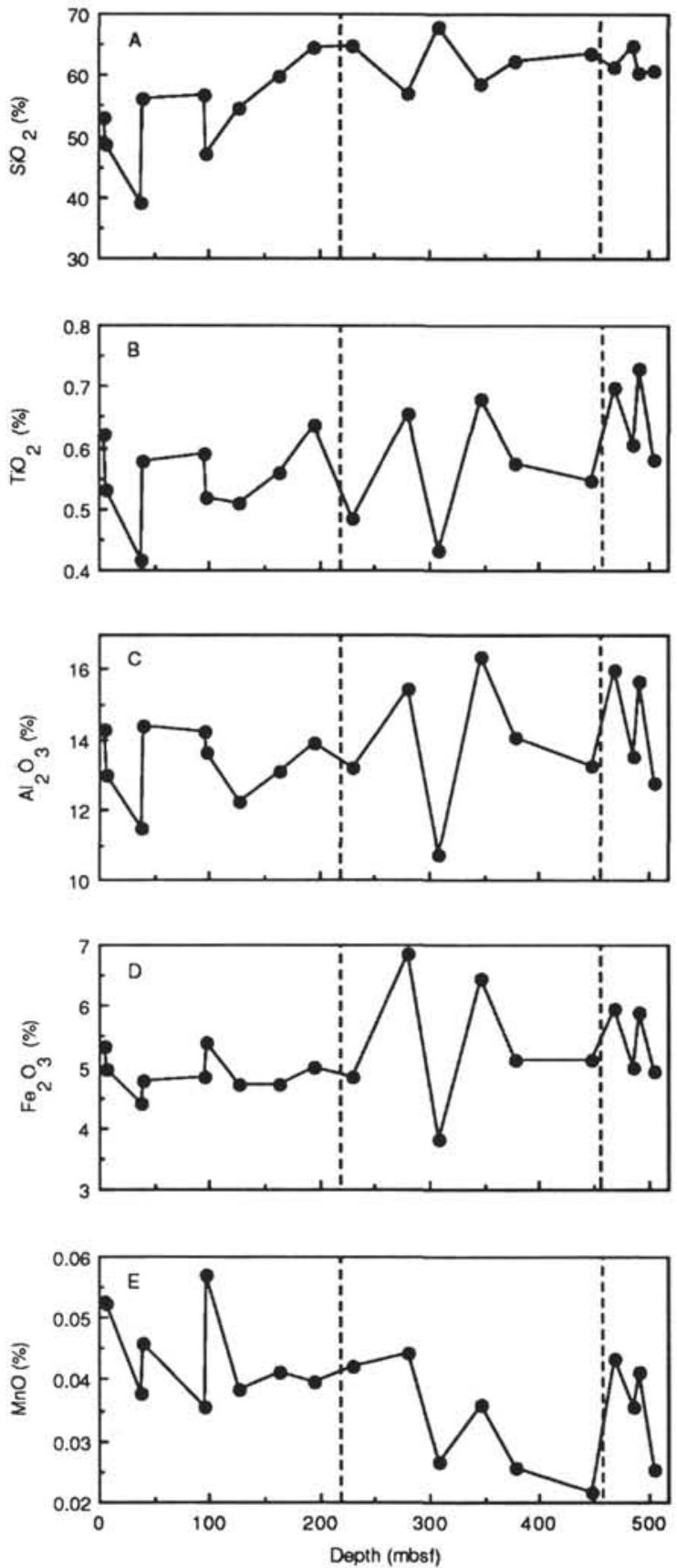

units: Unit I (0-170 mbsf, Quaternary to late Pliocene), Unit II (170-457 mbsf, late Pliocene to late Miocene), Unit III (457-800 mbsf, late to middle Miocene), Unit IV ( $800-1020$ mbsf, middle to early Miocene), and Unit V (1020-1084 mbsf, early Miocene). The average sedimentation rate was about $70 \mathrm{~m} / \mathrm{m}$.y., although the rate ranged from $15 \mathrm{~m} / \mathrm{m}$.y. to $175 \mathrm{~m} / \mathrm{m}$.y (Ingle, Suyehiro, von Breymann, et al., 1990).

Determined concentrations of the analyzed elements are listed in Table 3 (for major and minor elements) and Table 4 (for trace elements). Depth profiles of elemental concentrations are shown in Figure 4 (for major and minor elements) and Figure 5 (for trace elements).
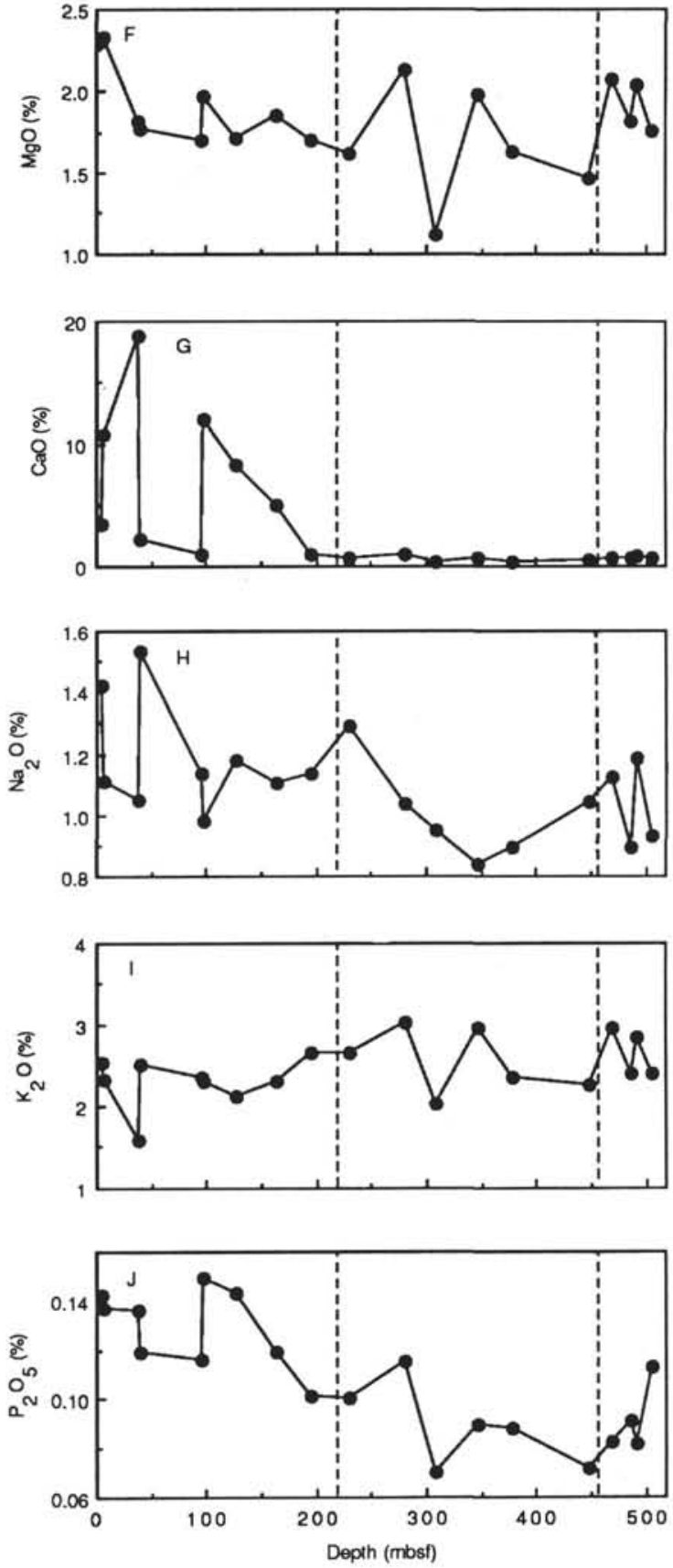

Figure 2. Depth profiles of major and minor element contents (\%) in the sediments from Site 798: $\mathbf{A} \cdot \mathrm{SiO}_{2}$. B. $\mathrm{TiO}_{2} \cdot$ C. $\mathrm{Al}_{2} \mathrm{O}_{3}$. D. $\mathrm{Fe}_{2} \mathrm{O}_{3}$ (total iron). E. MnO. F. MgO. G. CaO. H. $\mathrm{Na}_{2} \mathrm{O}$. I. $\mathrm{K}_{2} \mathrm{O}$. J. $\mathrm{P}_{2} \mathrm{O}_{5}$. Broken lines indicate boundaries between lithological units. 
Table 2. Trace element concentrations in the sediments from Site 798.

\begin{tabular}{|c|c|c|c|c|c|c|c|c|c|c|c|c|c|c|c|}
\hline $\begin{array}{l}\text { Sample } \\
\text { no. }\end{array}$ & $\begin{array}{l}\text { Core, section, } \\
\text { interval }(\mathrm{cm})\end{array}$ & $\begin{array}{l}\text { Depth } \\
\text { (mbsf) }\end{array}$ & $\begin{array}{c}\text { As } \\
\text { (ppm) }\end{array}$ & $\begin{array}{c}\mathrm{Ba} \\
(\mathrm{ppm})\end{array}$ & $\begin{array}{c}\mathrm{Br} \\
(\mathrm{ppm})\end{array}$ & $\begin{array}{c}\text { Co } \\
(\mathrm{ppm})\end{array}$ & $\underset{(\mathrm{ppm})}{\mathrm{Cr}}$ & $\begin{array}{c}\mathrm{Cs} \\
(\mathrm{ppm})\end{array}$ & $\begin{array}{c}\mathrm{Hf} \\
(\mathrm{ppm})\end{array}$ & $\begin{array}{c}\mathrm{Sb} \\
(\mathrm{ppm})\end{array}$ & $\begin{array}{c}\mathrm{Sc} \\
(\mathrm{ppm})\end{array}$ & $\begin{array}{c}\mathrm{Ta} \\
(\mathrm{ppm})\end{array}$ & $\begin{array}{c}\text { Th } \\
\text { (ppm) }\end{array}$ & $\underset{(\mathrm{ppm})}{\mathrm{U}}$ & $\begin{array}{c}\mathrm{La} \\
(\mathrm{ppm})\end{array}$ \\
\hline 1 & $798 \mathrm{~A}-1 \mathrm{H}-4,86-88$ & 5.36 & 6 & 963 & 90 & 13.2 & 65 & 8.4 & 3.5 & 1.6 & 13.6 & 1.8 & 12.4 & 8.5 & 32.6 \\
\hline 2 & 1H-5, 94-96 & 6.94 & 12 & 917 & 28 & 12.5 & 57 & 8.0 & 3.1 & 3.2 & 12.6 & 1.6 & 11.0 & 7.7 & 30.6 \\
\hline 3 & $5 \mathrm{H}-2,86-88$ & 39.06 & 6 & 664 & 23 & 11.4 & 52 & 6.9 & 2.9 & 1.7 & 11 & 1.5 & 10.0 & 4.7 & 30.6 \\
\hline 4 & $5 \mathrm{H}-3,85-82$ & 40.55 & 11 & 805 & 74 & 9.8 & 59 & 7.0 & 4.1 & 1.1 & 11.1 & 3,1 & 12.3 & 13.7 & 36.3 \\
\hline 5 & $11 \mathrm{H}-2,97-99$ & 96.57 & 13 & 828 & 76 & 10.3 & 81 & 7.9 & 3.1 & 1.1 & 12.3 & 1.5 & 11.6 & 14.7 & 29.7 \\
\hline 6 & $11 \mathrm{H}-3,90-92$ & 98.00 & 6 & 799 & 22 & 14.5 & 61 & 7.8 & 3.1 & 1.4 & 12.5 & 1.4 & 11.1 & 9.2 & 32.1 \\
\hline 7 & $798 \mathrm{~B}-14 \mathrm{H}-4,92-94$ & 127.51 & 4 & 705 & 46 & 11.3 & 60 & 6.9 & 3.0 & 0.9 & 12.2 & 1.6 & 10.6 & 7.4 & 28.3 \\
\hline 8 & $18 X-2,90-92$ & 164.30 & 7 & 830 & 27 & 12.0 & 62 & 7.0 & 3.2 & 1.3 & 11.3 & 1.6 & 11.8 & 4.4 & 29.5 \\
\hline 9 & $21 X-4,98-100$ & 195.79 & 6 & 982 & 20 & 13.2 & 62 & 7.7 & 3.6 & 1.0 & 12.8 & 2.6 & 13.2 & 4.3 & 34.6 \\
\hline 10 & $25 X-1,95-97$ & 230.65 & 5 & 825 & 25 & 5.6 & 47 & 5.4 & 3.0 & 1.1 & 8.5 & 2.3 & 9.9 & 5.4 & 25.5 \\
\hline 11 & $30 X-3,90-92$ & 281.10 & 24 & 999 & 25 & 21.7 & 80 & 9.9 & 3.3 & 2.0 & 14.4 & 1.9 & 14.0 & 7.5 & 35.8 \\
\hline 12 & $33 X-2,90-92$ & 308.10 & 9 & 1083 & 27 & 10.3 & 66 & 7.8 & 4.5 & 1.1 & 12.2 & 4.0 & 14.6 & 25.1 & 40.2 \\
\hline 13 & $37 X-3,10-12$ & 347.30 & 11 & 1085 & 12 & 12.5 & 84 & 10.4 & 3.5 & 1.1 & 15.6 & 1.9 & 14.1 & 6.0 & 36.6 \\
\hline 14 & $40 X-4,123-125$ & 378.93 & 14 & 1252 & 18 & 14.7 & 68 & 7.9 & 3.1 & 1.5 & 13.2 & 1.9 & 11.7 & 8.5 & 31.7 \\
\hline 15 & $43 X-5,90-92$ & 409.10 & 9 & 829 & 9 & 17.7 & 60 & 8.9 & 3.7 & 1.4 & 14.7 & 2.1 & 13.0 & 7.1 & 34.4 \\
\hline 16 & $47 X-6,30-32$ & 447.43 & 17 & 903 & 19 & 10.5 & 49 & 6.9 & 6.3 & 1.5 & 11.9 & 6.1 & 15.5 & 5.5 & 57.7 \\
\hline 17 & $49 X-6,88-90$ & 468.48 & 12 & 957 & 7 & 24.5 & 62 & 9.0 & 4.2 & 1.8 & 16.8 & 1.8 & 12.9 & 5.5 & 36.6 \\
\hline 18 & $51 X-5,90-92$ & 486.30 & 6 & 870 & 6 & 12.9 & 60 & 7.0 & 3.9 & 2.0 & 13.7 & 2.1 & 11.0 & 4.6 & 31.5 \\
\hline 19 & $52 X-2,88-90$ & 491.38 & 11 & 2325 & 17 & 23.7 & 83 & 8.7 & 3.8 & 2.1 & 17.9 & 1.6 & 11.4 & 6.7 & 33.1 \\
\hline 20 & $53 X-5,42-44$ & 505.12 & 11 & 1032 & 19 & 11.5 & 100 & 7.7 & 3.2 & 2.4 & 16.0 & 1.2 & 10.5 & 9.1 & 28.8 \\
\hline
\end{tabular}

\section{DISCUSSION}

\section{Major and Minor Element Geochemistry}

\section{Site 798}

As plotted in Figure $2 \mathrm{~A}$, the $\mathrm{SiO}_{2}$ content gradually increases with sub-bottom depth up to 200 mbsf. Beneath about $200 \mathrm{mbsf}$, the $\mathrm{SiO}_{2}$ content is nearly constant at around $60 \%$. At the upper sections of the core (above about $200 \mathrm{mbsf}$ ), the $\mathrm{SiO}_{2}$ content in the two samples is very low, because calcium carbonates develop in the samples as shown in the depth profile of $\mathrm{CaO}$ content (Fig. 2G). Calcium content in the samples in the lower sections of the core (below about 200 mbsf) is less than $1 \%$. At these sections of the sediment column dilution with calcium carbonates does not lead to decrease in the contents of other elements. Depth profiles of $\mathrm{Al}_{2} \mathrm{O}_{3}$ and TiO $\mathrm{T}_{2}$ contents (Fig. 2C and $\mathrm{B}$ ) in the upper sections are identical to the depth profile of $\mathrm{SiO}_{2}$ content (Fig. 2A). Aluminum and titanium are regarded as elements derived from terrigenous detritus, and $\mathrm{Si} / \mathrm{Al}$ ratio of terrigenous silicate is around three (Leinen, 1977), which is nearly identical to the ratios of the sediments from the portions of the sediment column. Such similarity among depth profiles of $\mathrm{SiO}_{2}, \mathrm{Al}_{2} \mathrm{O}_{3}$, and $\mathrm{TiO}_{2}$ contents in the upper sections of the core suggests that silica will also be supplied in the form of aluminosilicates derived from terrigenous materials. Contents of these elements can vary with degree of dilution by calcium carbonates, whereas the $\mathrm{Si} / \mathrm{Al}$ ratio is preserved. However, in the lower sections (below about $120 \mathrm{mbsf}$ ), the depth profiles of $\mathrm{Al}_{2} \mathrm{O}_{3}$ and $\mathrm{TiO}_{2}$ contents are different from that of $\mathrm{SiO}_{2}$ content: $\mathrm{SiO}_{2}$ content (Fig. 2A) inversely changes against $\mathrm{Al}_{2} \mathrm{O}_{3}$ (Fig. 2C) and $\mathrm{TiO}_{2}$ contents (Fig. 2B). Such a difference in depth profiles suggests incorporation of biogenic silica into the sediments.

The depth profile of $\mathrm{Fe}_{2} \mathrm{O}_{3}$ content (Fig. 2D) below about $200 \mathrm{mbsf}$ is also similar to the depth profiles of $\mathrm{Al}_{2} \mathrm{O}_{3}$ and $\mathrm{TiO}_{2}$ contents, suggesting terrigenous supply of iron into the sediment column. However, in the upper sections variation of $\mathrm{Fe}_{2} \mathrm{O}_{3}$ content is much smaller than those of $\mathrm{SiO}_{2}, \mathrm{Al}_{2} \mathrm{O}_{3}$, and $\mathrm{TiO}_{2}$ contents (Fig. $2 \mathrm{~A}, \mathrm{C}$, and $\mathrm{B}$, respectively), which implies that some of the iron in the upper sections is contained in the iron-bearing minerals formed through hydrogenous precipitation and diagenetic processes. Contents of $\mathrm{Na}_{2} \mathrm{O}, \mathrm{K}_{2} \mathrm{O}, \mathrm{P}_{2} \mathrm{O}_{5}$, and $\mathrm{MgO}$ (Fig. $2 \mathrm{H}$, $\mathrm{I}$, J, and $\mathrm{F}$, respectively) in the lower column also correlate with $\mathrm{Al}_{2} \mathrm{O}_{3}$ content. However, the depth profiles of contents of these elements in the upper sections differ from the depth profile of $\mathrm{Al}_{2} \mathrm{O}_{3}$ content, suggesting diagenesis and the contribution of other source materials. Content of $\mathrm{MnO}$, ranging from $0.02 \%$ to $0.06 \%$, correlates poorly with $\mathrm{Al}_{2} \mathrm{O}_{3}$ and $\mathrm{TiO}_{2}$ contents throughout the sediment column. Manganese seems to be supplied in the form of hydrogenous precipitates, and may migrate to the sediment column after burial.

\section{Site 799}

The content of $\mathrm{SiO}_{2}$ in the sediments from Site 799 (Fig. 4A) ranges from $40 \%$ to $80 \%$, with several exceptions where calcium or manganese carbonates are dominant, as seen in the depth profiles of $\mathrm{CaO}$ (Fig. 4G) or $\mathrm{MnO}$ (Fig. 4E) content. The depth profile of $\mathrm{Al}_{2} \mathrm{O}_{3}$ content (Fig. 4C) agrees well with that of the $\mathrm{TiO}_{2}$ content (Fig. 4B) throughout the column. As has been mentioned, such agreement between the depth profiles was also seen in the sediment column from Site 798. Similar depth profiles of $\mathrm{Al}_{2} \mathrm{O}_{3}$ and $\mathrm{TiO}_{2}$ contents imply that both elements were supplied as terrigenous detritus with a similar $\mathrm{Al} / \mathrm{Ti}$ ratio. The depth profile of $\mathrm{SiO}_{2}$ content is different from those of $\mathrm{Al}_{2} \mathrm{O}_{3}$ and $\mathrm{TiO}_{2}$ contents, especially in several samples diluted by carbonates. This suggests that siliceous biogenics (e.g., diatoms) precipitated through sedimentation at a rate different from that for terrigenous detritus, and that diagenetic processes affect the depth profile of $\mathrm{SiO}_{2}$ content. The depth profile of $\mathrm{Fe}_{2} \mathrm{O}_{3}$ content (Fig. 4D) at the sections beyond $540 \mathrm{mbsf}$ agrees well with depth profiles of $\mathrm{Al}_{2} \mathrm{O}_{3}$ and $\mathrm{TiO}_{2}$ contents (Fig. $4 \mathrm{C}$ and $\mathrm{B}$, respectively). At the sections below $540 \mathrm{mbsf}$, the depth profile of $\mathrm{Fe}_{2} \mathrm{O}_{3}$ content does not correlate with the profiles of $\mathrm{Al}_{2} \mathrm{O}_{3}$ and $\mathrm{TiO}_{2}$ contents, suggesting the contribution of other materials bearing iron in the older sedimentation. In particular, the $\mathrm{Fe}_{2} \mathrm{O}_{3}$ content is substantially low at around $750-950$ mbsf, where rhyolitic clastics are abundant, as shown in lithological descriptions of the sediment column (Ingle, Suyehiro, von Breymann, et al., 1990). The relationshipamong $\mathrm{Al}_{2} \mathrm{O}_{3}, \mathrm{TiO}_{2}$, and $\mathrm{Fe}_{2} \mathrm{O}_{3}$ contents restricts the chemical compositions of the materials supplied by rhyolitic volcanism. Perhaps the Al/Ti ratios of the volcanic materials were identical to the ratios of the terrigenous detritus supplied throughout the sedimentation of the column. However, less iron was contained in the volcanic materials.

It is also remarkable in depth profiles of major and minor elements that the $\mathrm{MnO}$ content is extraordinarily high in a part of the column, as plotted in Fig. 4E. The manganese content is above $0.1 \%$ in more than half of the samples analyzed. Besides, the $\mathrm{MnO}$ content exceeds $1 \%$ (up to $18 \%$ ) in several samples. Such accumulation of manganese at the particular positions of the sediment column is extensively discussed by Matsumoto (this volume). Such high $\mathrm{MnO}$ content is used as a measure of diagenetic formation of manganese-rich carbonate concretions which were abundant in the sediment column (Ingle, Suyehiro, von Breymann, et al., 1990; Matsumoto, this volume). No other elements show such a depth profile in the sediment column. Manganese geochemistry of modern sediments in the Japan Sea is influ- 
Table 2 (continued).

\begin{tabular}{ccccccc}
\hline $\begin{array}{c}\text { Sample } \\
\text { no. }\end{array}$ & $\begin{array}{c}\text { Ce } \\
(\mathrm{ppm})\end{array}$ & $\begin{array}{c}\mathrm{Sm} \\
(\mathrm{ppm})\end{array}$ & $\begin{array}{c}\mathrm{Eu} \\
(\mathrm{ppm})\end{array}$ & $\begin{array}{c}\mathrm{Tb} \\
(\mathrm{ppm})\end{array}$ & $\begin{array}{c}\mathrm{Yb} \\
(\mathrm{ppm})\end{array}$ & $\begin{array}{c}\mathrm{Lu} \\
(\mathrm{ppm})\end{array}$ \\
\hline 1 & 71 & 5.5 & 1.3 & 0.70 & 2.2 & 0.53 \\
2 & 64 & 5.7 & 1.2 & 0.76 & 2.2 & 0.41 \\
3 & 59 & 4.9 & 1.1 & 0.68 & 1.8 & 0.31 \\
4 & 75 & 5.8 & 1.1 & 0.79 & 2.3 & 0.58 \\
5 & 65 & 4.8 & 1.1 & 0.69 & 1.9 & 0.58 \\
6 & 70 & 4.7 & 1.2 & 0.66 & 2.1 & 0.55 \\
7 & 58 & 4.6 & 1.0 & 0.62 & 1.9 & 0.54 \\
8 & 64 & 4.7 & 1.1 & 0.81 & 1.9 & 0.37 \\
9 & 79 & 5.2 & 1.4 & 0.62 & 1.9 & 0.40 \\
10 & 57 & 3.6 & 1.4 & 0.52 & 1.6 & 0.32 \\
11 & 79 & 6.6 & 1.4 & 0.97 & 2.5 & 0.62 \\
12 & 91 & 5.8 & 1.2 & 0.74 & 2.0 & 0.42 \\
13 & 78 & 6.0 & 1.3 & 0.69 & 2.2 & 0.43 \\
14 & 70 & 5.5 & 1.2 & 0.80 & 2.0 & 0.55 \\
15 & 81 & 6.5 & 1.3 & 0.82 & 2.3 & 0.36 \\
16 & 124 & 7.6 & 1.1 & 1.12 & 2.8 & 0.55 \\
17 & 88 & 7.0 & 1.5 & 1.12 & 2.6 & 0.44 \\
18 & 75 & 5.6 & 1.2 & 1.06 & 2.3 & 0.50 \\
19 & 85 & 5.9 & 1.4 & 0.86 & 2.6 & 0.54 \\
20 & 74 & 6.4 & 1.4 & 0.83 & 2.8 & 0.40 \\
\hline
\end{tabular}

enced by oxidation-reduction conditions and water depth (Masuzawa, 1987). The large differences in $\mathrm{MnO}$ content between Sites 798 and 799 may be related to differences in water depth at sedimentation.

Iron was also partly contained in carbonate minerals (Matsumoto, this volume; Minai et al., this volume). However, the depth profile of $\mathrm{Fe}_{2} \mathrm{O}_{3}$ content agrees with those of $\mathrm{Al}_{2} \mathrm{O}_{3}$ and $\mathrm{TiO}_{2}$ contents, at least over $540 \mathrm{mbsf}$. This means that most of the iron is not contained in carbonates, in contrast to manganese. The correlation between $\mathrm{Fe}_{2} \mathrm{O}_{3}$ and $\mathrm{Al}_{2} \mathrm{O}_{3}$ contents is shown in Figure 6. Except for samples $26,41,44,53$, and $57, \mathrm{Al} / \mathrm{Fe}$ ratio is almost constant throughout the column. Samples 26 and 57, whose $\mathrm{Fe}_{2} \mathrm{O}_{3}$ contents are excessive in comparison with their $\mathrm{Al}_{2} \mathrm{O}_{3}$ contents, contain large amounts of carbonate minerals (Matsumoto, this volume): rhodochrosite and magnesite (sample 26), and dolomite (sample 57), suggesting that substantial amounts of iron may be contained in carbonate minerals in these samples. In contrast, $\mathrm{Fe}_{2} \mathrm{O}_{3}$ content in samples 41,44 , and 53 is substantially less than what would be expected based on their $\mathrm{Al}_{2} \mathrm{O}_{3}$ content. Because $\mathrm{Al}_{2} \mathrm{O}_{3}$ content correlates with $\mathrm{TiO}_{2}$ content, it is not likely that aluminum is selectively enriched in these samples. Perhaps terrigenous detritus or volcanic material with lower $\mathrm{Fe}_{2} \mathrm{O}_{3}$ content was supplied during the sedimentation of samples 41,44 , and 53 .

Depth profiles of $\mathrm{Na}_{2} \mathrm{O}$ and $\mathrm{K}_{2} \mathrm{O}$ contents also agree with those of $\mathrm{Al}_{2} \mathrm{O}_{3}$ and $\mathrm{TiO}_{2}$ contents. Similar depth profiles of $\mathrm{Al}_{2} \mathrm{O}_{3}, \mathrm{TiO}_{2}, \mathrm{Na}_{2} \mathrm{O}$, and $\mathrm{K}_{2} \mathrm{O}$ contents suggest that most of the sodium and potassium in the sediments was also supplied from terrigenous sources throughout the sedimentation. Figure 7 shows the correlation between $\mathrm{Na}_{2} \mathrm{O}$ and $\mathrm{K}_{2} \mathrm{O}$ contents. In most of the samples, $\mathrm{K}_{2} \mathrm{O} / \mathrm{Na}_{2} \mathrm{O}$ ratios are around 2, whereas the ratios in samples $41,42,44,50$, and 53 are quite different from those in the others. This may imply that another source material with a different $\mathrm{K} / \mathrm{Na}$ ratio contributed to sedimentation of these samples. However, we must be very careful in utilizing the ratio to characterize the source materials in the sediments because the $\mathrm{K}_{2} \mathrm{O} / \mathrm{Na}_{2} \mathrm{O}$ ratio can largely change with diagenetic alteration of the volcanic materials. As has been reported in the studies on low-temperature alteration of abyssal tholeiites (Hart, 1969; Hart and Staudigel, 1982), the ratio increases with degree of alteration with accumulation of potassium into the secondary minerals formed in low-temperature alteration. The Japan Sea sediments analyzed in this work contain relatively large amounts of volcanic materials. Such diagenetic processes may affect the variations in the $\mathrm{K}_{2} \mathrm{O} / \mathrm{Na}_{2} \mathrm{O}$ ratios of the sediments. Depth profiles of $\mathrm{P}_{2} \mathrm{O}_{5}$ (Fig. 4J) and MgO contents (Fig. $4 \mathrm{~F}$ ) are totally different from the depth profiles of the elements from terrigenous detritus (e.g., aluminum). Magnesium content is particularly high in some samples where carbonates are abundant.

\section{Trace Element Geochemistry}

The geochemistry of trace elements, except for REE, in the sediments from Site 798 and 799 is discussed in this section. The determined trace elements (except for REE) are $\mathrm{As}, \mathrm{Ba}, \mathrm{Br}, \mathrm{Co}, \mathrm{Cr}$, $\mathrm{Cs}, \mathrm{Hf}, \mathrm{Sb}, \mathrm{Sc}, \mathrm{Ta}, \mathrm{Th}$, and U. The geochemistry of REE's will be discussed in the next section in comparison with that of major, minor, and other trace elements.

\section{Site 798}

Figure 3 presents depth profiles of the elements discussed in this section. It is sometimes difficult to interpret geochemical behaviors of trace elements in sediment columns from such depth profiles because the depth profile tends to be affected by occasional dilution (e.g., with carbonates). Usually, the elemental ratio (or correlation) of two elements can provide more information for interpreting the geochemistry of trace elements in sediments because such occasional incorporation of materials does not influence the depth profile of the elemental ratio.

Figure 8 shows the depth profile of the Th/Sc ratio. The ratio shows mixing proportions between terrigenous detritus from continental crust (Th/Sc $=1$, Taylor and McLennan, 1985) and andesitic-to-basic volcanics (e.g., $\mathrm{Th} / \mathrm{Sc}=0.16$ for andesite crust and $\mathrm{Th} / \mathrm{Sc}<0.01$ for oceanic crust, Taylor and McLennan, 1985). As reported, the ratio has been successively applied in turbidite sedimentation near continents (McLennan et al., 1990). As is seen in Figure 8, the ratio is almost 1 through the column, with slight depletion in the sections below 400 mbsf, implying that terrigenous material of $\mathrm{Th} / \mathrm{Sc}=1$ was supplied throughout sedimentation, but volcanic material related to island-arc or basin-type volcanism was more active in the Pliocene than in the Quaternary. The ratio of surface sediments at the Japan Sea (Minai, 1982 ) is about 1 , indicating dominant contribution of continental crust in sedimentation of the modern Japan Sea. The constant $\mathrm{Th} / \mathrm{Sc}$ ratio suggests that similar sedimentation processes have occurred throughout the Quaternary and late Pliocene in the Japan Sea.

In Figure 9, correlations between $\mathrm{Cr}(\mathrm{ppm})$ and $\mathrm{Al}_{2} \mathrm{O}_{3}(\%)$ are shown with open circles. Although two samples (12 and 20) indicate enrichment of chromium relative to aluminum, correlation between the two elements is fairly good, suggesting that chromium was also supplied from terrigenous sources to the sediment column.

\section{Site 799}

The depth profile of the Th/Sc ratio is plotted in Figure 10. The ratio gradually decreased with depth, from about 1 (Quaternary) to about $0.6-0.7$ (Miocene). Since the Th/Sc ratio reflects incorporation of andesitic and basaltic materials, the depth profile of the $\mathrm{Th} / \mathrm{Sc}$ ratio suggests a greater contribution of andesitic and basaltic materials in sedimentation at Kita-Yamato Trough from the Miocene to the Pliocene. However, several samples (samples 4, 15, 17, 41, 50, and 51) show much higher $\mathrm{Th} / \mathrm{Sc}$ ratios than the ratio estimated from interpolation in the depth profile. A high concentration of thorium relative to scandium concentration may reflect rhyolitic volcanic activity in the sedimentation of the samples. Some of the samples differ in chemical compositions from the other sediments: carbonate concretion is abundant in sample 4, and the chemical compositions of samples 41,50, and 51 (Tables 3 and 4) are quite different from the adjacent sediments, as shown in the depth profiles (Figs. 4 and 5). However, no remarkable differences in chemical compositions are seen for samples 15 and 17. Analysis of more samples from these sections may provide further information on variation of sedimentary history in those periods.

In Figure 9 correlations between $\mathrm{Cr}$ concentration (ppm) and $\mathrm{Al}_{2} \mathrm{O}_{3}$ content $(\%)$ are shown with dots. A good correlation between concentrations of the two elements suggests that terrigenous detritus again is the major source of chromium in sedimentation for Site 799. The aluminum content is also correlated with $\mathrm{Cs}, \mathrm{Hf}, \mathrm{Ta}$, and $\mathrm{Th}$ 

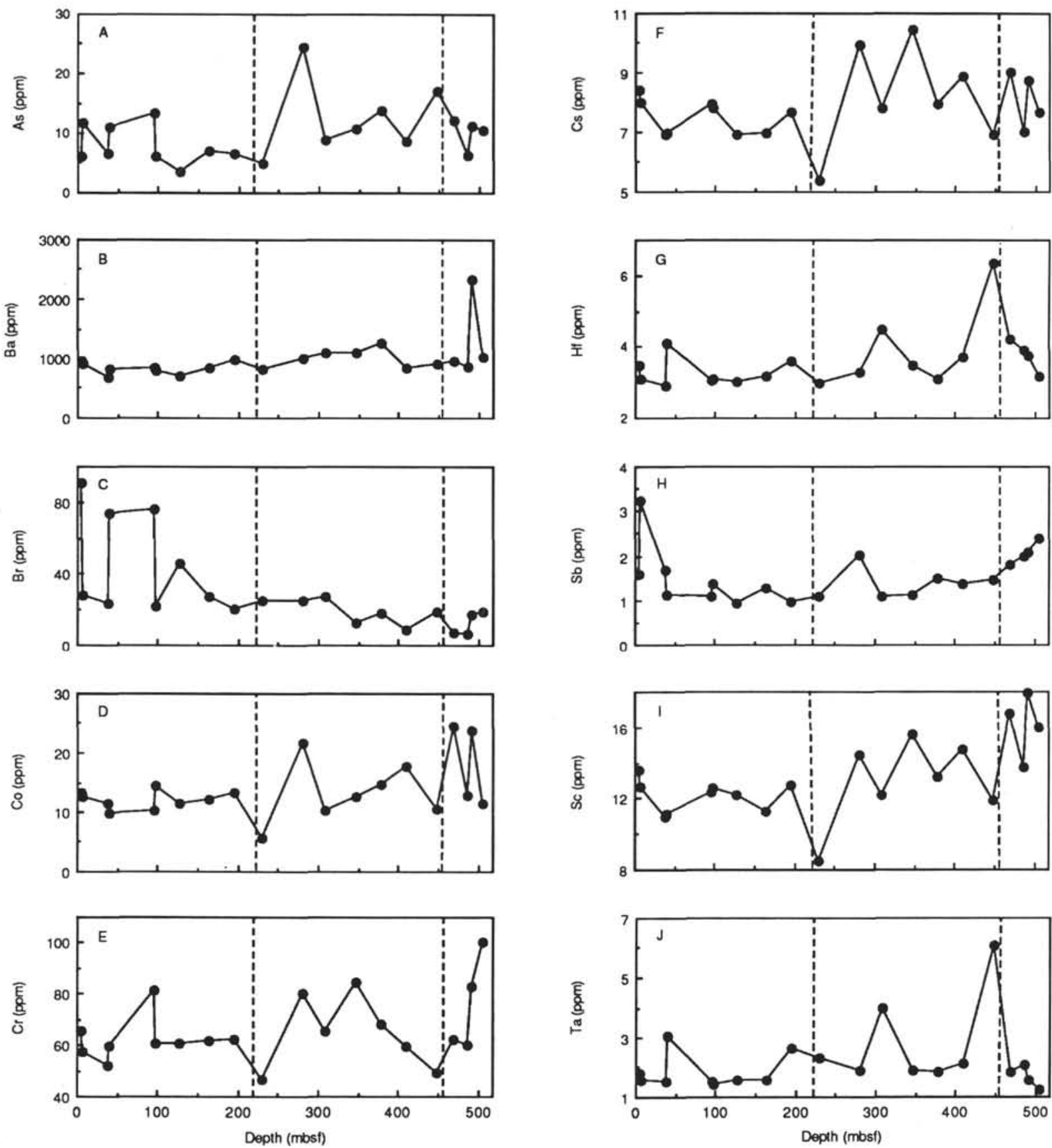

Figure 3. Depth profiles of trace element concentrations (ppm) in the sediments from Site 798: A. As. B. Ba. C. Br. D. Co. E. Cr. F. Cs. G. Hf. H. Sb. I. Sc. J. Ta. K. Th. L. U. M. La. N. Ce. O. Sm. P. Eu. Q. Tb. R. Yb. S. Lu. Broken lines indicate boundaries between lithological units.

concentrations. Such correlation also suggests association of these elements with aluminosilicates in terrigenous detritus. However, in samples $10,20,41,44,50$, and 53 , chromium concentration relative to $\mathrm{Al}_{2} \mathrm{O}_{3}$ content is very different from the concentration in the other samples (Fig. 9). Concentrations of cesium, hafnium, tantalum, and thorium in several samples also occasionally differ from those in all the other samples, which implies that these elements were sometimes incorporated into the sediment without association with aluminosilicates. It is well known that hafnium is present in zircon because of substitution for the zirconium ion. Deposition of such accessory minerals may lead to extraordinary abundances of these elements, as seen in their depth profiles (Fig. 5).
Concentrations of $\mathrm{As}, \mathrm{Ba}, \mathrm{Br}, \mathrm{Co}, \mathrm{Sb}$, and $\mathrm{U}$ do not correlate well with $\mathrm{Al}_{2} \mathrm{O}_{3}$ content. Concentration of barium increases with the depth (70-200 mbsf), and then decreases (200-580 mbsf) (Fig. 5B). Concentrations of $\mathrm{Br}$ and $\mathrm{Sb}$ (Fig. $5 \mathrm{C}$ and $\mathrm{H}$, respectively) are also high in the range from 100 to 600 mbsf. Such variations of elemental concentrations (especially barium concentration) with depth are interpreted as changes in sedimentation environment relating to change in water depth (von Breymann et al., 1990, and this volume). The depth profile of cobalt concentration (Fig. 5D) is essentially identical to those of Ba, $\mathrm{Br}$, and $\mathrm{Sb}$ concentrations (Fig. $5 \mathrm{~B}, \mathrm{C}$, and $\mathrm{H}$, respectively). However, the Co concentration is also high in the $600-750 \mathrm{mbsf}$ range, whereas $\mathrm{Ba}, \mathrm{Br}$, and $\mathrm{Sb}$ concentrations are not substantially high. Perhaps cobalt 

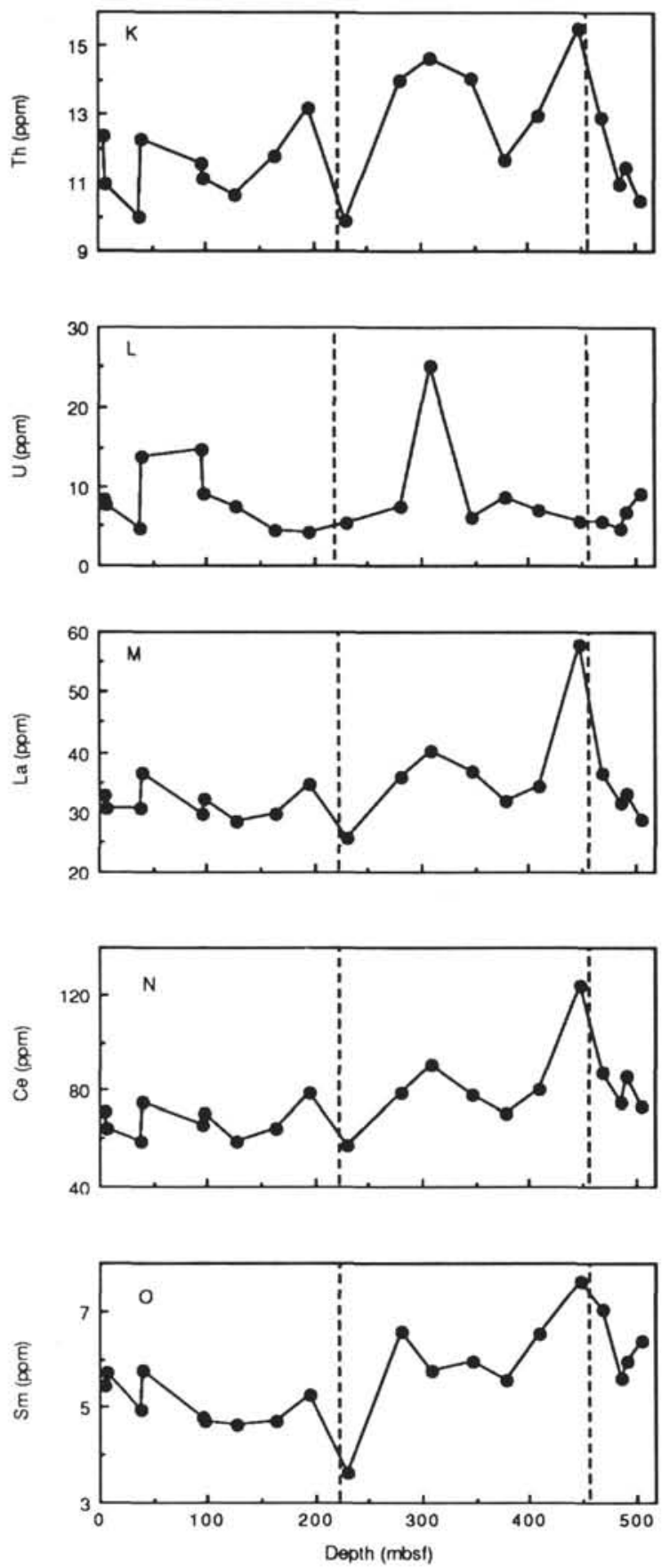

Figure 3 (continued).

was supplied to the sediments at that range by processes different from those supplying barium, bromine, and antimony.

\section{REE Geochemistry}

Figure 11 shows typical REE patterns (chondrite-normalized) of the Quaternary (Fig. 11A) and Pliocene (Fig. 11B) sediments from Site 799. The chondritic values used are those determined by Masuda et al., (1973). The REE patterns indicate LREE enrichment relative to HREE, implying that terrigenous detritus can be regarded as major sources supplying REE's to the sediments.

Depth profiles of $\mathrm{La} / \mathrm{Yb}, \mathrm{Ce} / \mathrm{Ce}^{*}$, and $\mathrm{Eu} / \mathrm{Eu} *$ ratios are shown in Figures 12 (Site 798) and 13 (Site 799); $\mathrm{Ce}^{*}$ and $\mathrm{Eu}^{*}$ are cerium and
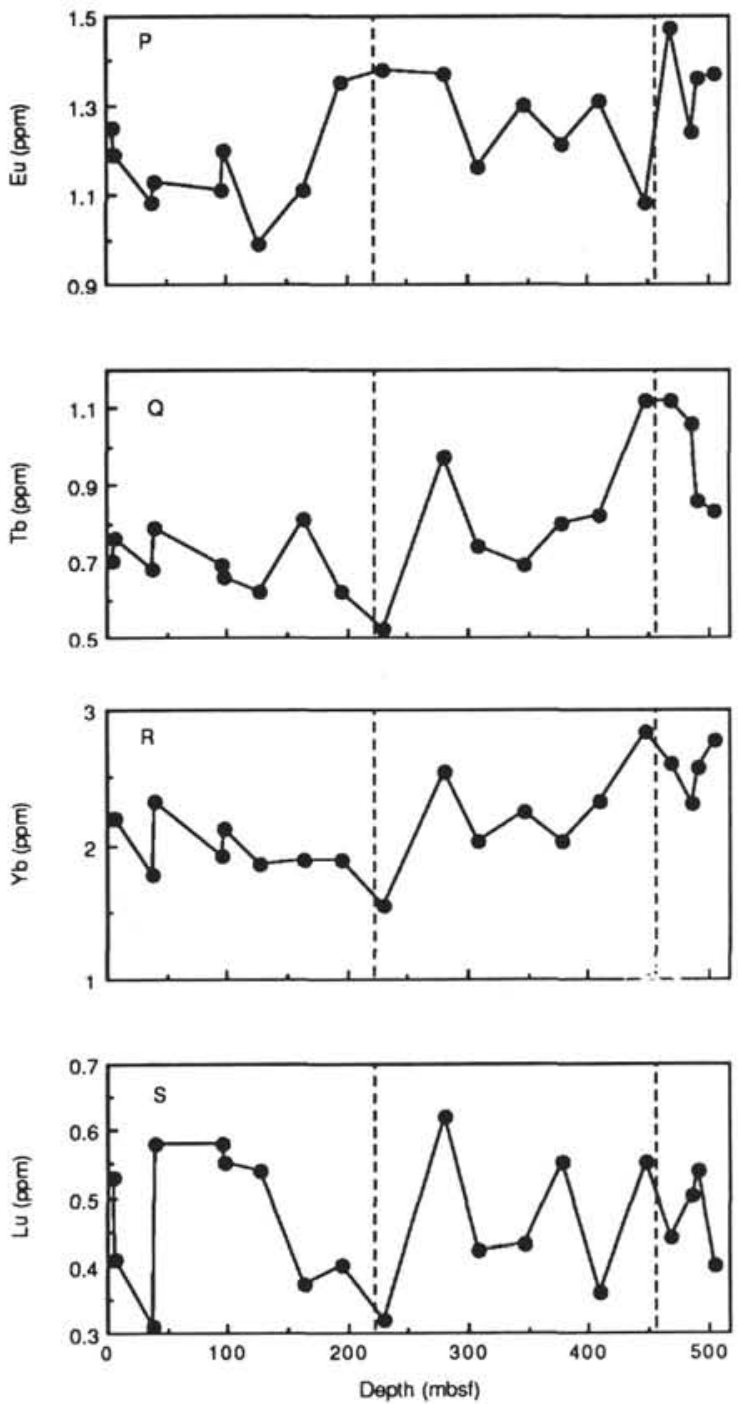

europium concentrations interpolated in a chondrite-normalized REE pattern assuming no cerium and europium anomalies. Values of $\mathrm{Ce}^{*}$ and $\mathrm{Eu}^{*}$ are calculated from chondrite-normalized concentrations of $\mathrm{La}, \mathrm{Sm}$, and $\mathrm{Tb}\left(\mathrm{La}_{\mathrm{N}}, \mathrm{Sm}_{\mathrm{N}}, \mathrm{Tb}_{\mathrm{N}}\right)$ and concentrations of $\mathrm{Ce}$ and $\mathrm{Eu}$ in chondrite ( $\mathrm{Ce}$ (chondrite) and $\mathrm{Eu}$ (chondrite)) using the following equations:

$$
\begin{aligned}
& \mathrm{Ce}^{*}=\mathrm{Ce}_{\text {(chondrite) }} \times\left(4 \times \mathrm{La}_{\mathrm{N}}-\mathrm{Sm}_{\mathrm{N}}\right) / 5, \\
& \mathrm{Eu}^{*}=\mathrm{Eu}_{\text {(chondrite) }} \times\left(2 \times \mathrm{Sm}_{\mathrm{N}}-\mathrm{Tb}_{\mathrm{N}}\right) / 3 .
\end{aligned}
$$

The $\mathrm{La} / \mathrm{Yb}$ ratios in Figures 12 and 13 indicate degree of LREE fractionation from HREE since lanthanum and ytterbium represent 

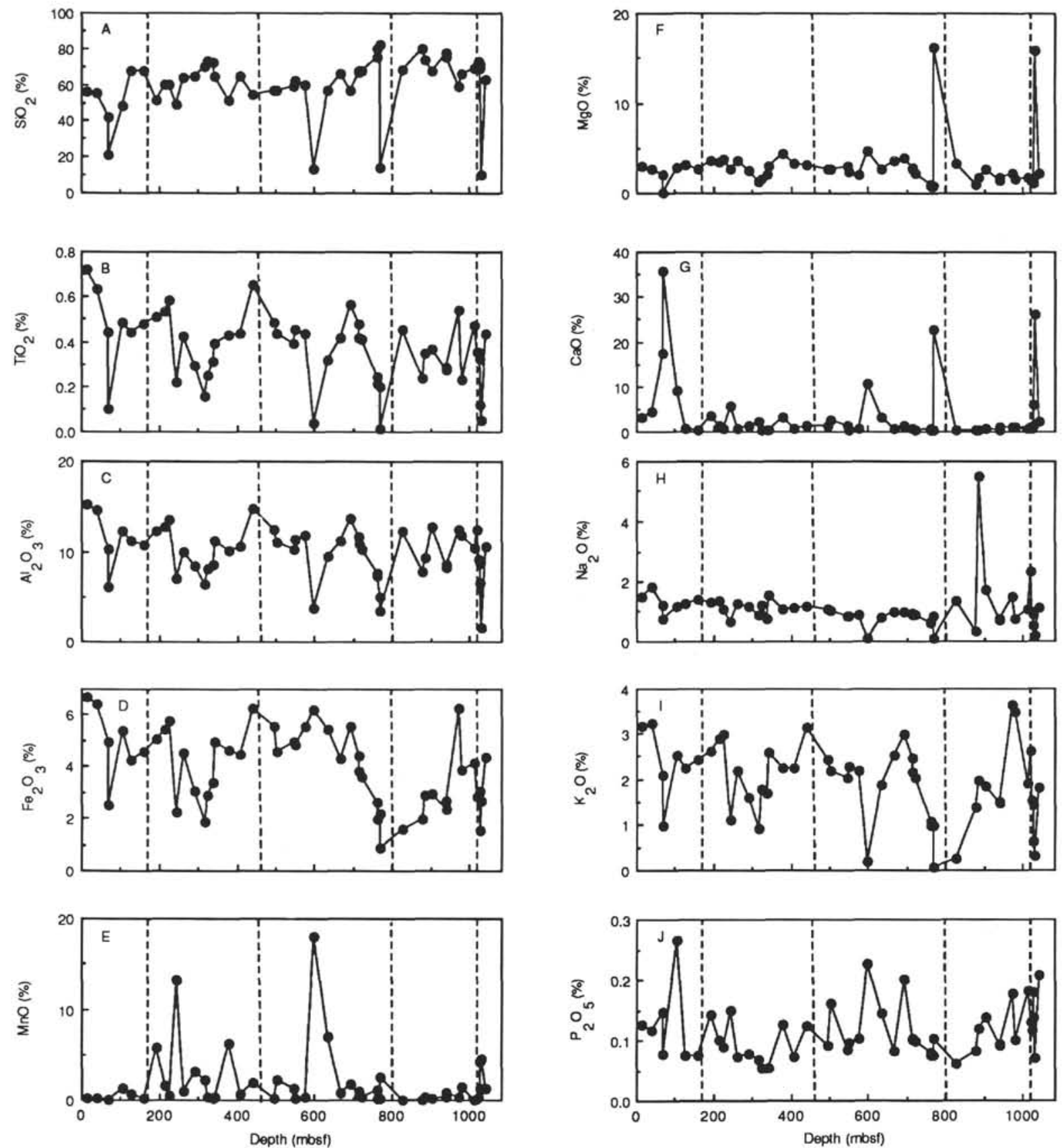

Figure 4. Depth profiles of major and minor element contents (\%) in the sediments from Site 799: A. $\mathrm{SiO}_{2} \cdot \mathbf{B} \cdot \mathrm{TiO}_{2} \cdot$ C. $\mathrm{Al}_{2} \mathrm{O}_{3} \cdot$ D. $\mathrm{Fe}_{2} \mathrm{O}_{3}$ (total iron). E. MnO. F. MgO. G. CaO. H. $\mathrm{Na}_{2} \mathrm{O}$. I. $\mathrm{K}_{2} \mathrm{O}$. J. $\mathrm{P}_{2} \mathrm{O}_{5}$. Broken lines indicate boundaries between lithological units.

LREE and HREE, respectively. The $\mathrm{Ce} / \mathrm{Ce} *$ and $\mathrm{Eu} / \mathrm{Eu}^{*}$ ratios (also plotted in Figures 12 and 13) indicate selective enrichment or depletion of cerium and europium from the other REE's. We can use the $\mathrm{Ce} / \mathrm{Ce}^{*}$ and $\mathrm{Eu} / \mathrm{Eu}^{*}$ ratios to represent degrees of anomaly of cerium and europium concentrations relative to concentrations of the other REE's.

Most $\mathrm{Ce} / \mathrm{Ce}$ * ratios of the sediments from Site 798 (Fig. 12B) are less than 1.15 , while they range from 1.25 to 1.7 in most of the sediments in the 200-750 mbsf range from Site 799 (Fig. 13B). Cerium anomalies have been reported in marine-derived substances: mud, carbonaceous ooze, hydrothermal metalliferous precipitate, seawater, fish debris, chert, and manganese nodule (e.g., Goldberg and Arrhenius, 1958; Piper, 1974; Murray et al., 1990; Shimizu and
Masuda, 1977; Toyoda et al., 1990; Matsumoto et al., 1988; Minai et al., 1985; Minai and Tominaga, 1989). In contrast, for continental crust and volcanic clastics on land, cerium anomalies have scarcely been reported (Henderson, 1984). Cerium tends to be oxidized to tetravalent state from trivalent state, which is the ordinary oxidation state of REE's, in marine environments. Oxidation of cerium in marine environments leads to behaviors of cerium that differ from those of the other trivalent REE's. However, europium, which is also unique for the stability of its divalent state, is trivalent, like the other REE's in normal marine environments (Henderson, 1984). It is notable that manganese nodules (e.g., Piper, 1974) and settling particles (Masuzawa and Koyama, 1989) tend to accumulate more cerium than the other trivalent REE's, suggesting association of cerium with 
Table 3. Major and minor element contents in the sediments from Site 799.

\begin{tabular}{|c|c|c|c|c|c|c|c|c|c|c|c|c|c|}
\hline $\begin{array}{l}\text { Sample } \\
\text { no. }\end{array}$ & $\begin{array}{l}\text { Core, section, } \\
\text { interval }(\mathrm{cm})\end{array}$ & $\begin{array}{l}\text { Depth } \\
\text { (mbsf) }\end{array}$ & $\begin{array}{l}\mathrm{SiO}_{2} \\
(\%)\end{array}$ & $\begin{array}{l}\mathrm{TiO}_{2} \\
(\%)\end{array}$ & $\begin{array}{c}\mathrm{Al}_{2} \mathrm{O}_{3} \\
(\%)\end{array}$ & $\begin{array}{l}\mathrm{Fe}_{2} \mathrm{O}_{3}{ }^{\mathrm{a}} \\
(\%)\end{array}$ & $\begin{array}{c}\mathrm{MnO} \\
(\%)\end{array}$ & $\begin{array}{c}\mathrm{MgO} \\
(\%)\end{array}$ & $\begin{array}{l}\mathrm{CaO} \\
(\%)\end{array}$ & $\begin{array}{c}\mathrm{Na}_{2} \mathrm{O} \\
(\%)\end{array}$ & $\begin{array}{l}\mathrm{K}_{2} \mathrm{O} \\
(\%)\end{array}$ & $\begin{array}{l}\mathrm{P}_{2} \mathrm{O}_{5} \\
(\%)\end{array}$ & $\begin{array}{l}\text { LOI } \\
(\%)\end{array}$ \\
\hline 1 & $799 \mathrm{~A}-3 \mathrm{H}-4,41-43$ & 15.61 & 55.68 & 0.72 & 15.26 & 6.70 & 0.08 & 2.90 & 3.10 & 1.50 & 3.15 & 0.126 & 10.80 \\
\hline 2 & $6 \mathrm{H}-2,44-46$ & 41.44 & 54.91 & 0.63 & 14.61 & 6.43 & 0.08 & 2.67 & 4.37 & 1.81 & 3.21 & 0.117 & 11.17 \\
\hline 3 & $9 \mathrm{H}-2,36-38$ & 70.16 & 41.96 & 0.44 & 10.27 & 4.91 & 0.04 & 1.99 & 17.46 & 1.19 & 2.08 & 0.146 & 19.20 \\
\hline 4 & $9 \mathrm{H}-2,133-135$ & 71.13 & 21.28 & 0.10 & 6.02 & 2.51 & 0.07 & 0.06 & 35.73 & 0.76 & 0.96 & 0.077 & 31.91 \\
\hline 5 & $12 \mathrm{H}-6,43-45$ & 105.63 & 48.22 & 0.48 & 12.32 & 5.39 & 1.24 & 2.84 & 9.11 & 1.18 & 2.53 & 0.266 & 16.44 \\
\hline 6 & $15 \mathrm{H}-2,39-41$ & 127.99 & 67.37 & 0.44 & 11.12 & 4.22 & 0.66 & 3.11 & 0.58 & 1.24 & 2.23 & 0.075 & 8.96 \\
\hline 7 & $18 \mathrm{H}-5,40-42$ & 161.6 & 67.16 & 0.48 & 10.62 & 4.55 & 0.22 & 2.63 & 0.43 & 1.39 & 2.41 & 0.074 & 10.03 \\
\hline 8 & $22 X-1,91-93$ & 194.71 & 51.42 & 0.51 & 12.18 & 5.02 & 5.80 & 3.50 & 3.38 & 1.30 & 2.60 & 0.143 & 14.14 \\
\hline 9 & $24 X-2,40-42$ & 215.00 & 59.49 & 0.53 & 12.70 & 5.40 & 1.59 & 3.45 & 1.25 & 1.36 & 2.89 & 0.101 & 11.24 \\
\hline 10 & $25 X-2,41-43$ & 224.71 & 59.35 & 0.58 & 13.53 & 5.77 & 0.40 & 3.69 & 0.63 & 1.07 & 2.97 & 0.089 & 11.93 \\
\hline 11 & $27 X-3,126-128$ & 245.66 & 48.52 & 0.21 & 6.93 & 2.24 & 13.19 & 2.65 & 5.64 & 0.65 & 1.09 & 0.148 & 18.74 \\
\hline 12 & $30 X-2,40-42$ & 262.40 & 63.53 & 0.42 & 9.99 & 4.51 & 0.95 & 3.56 & 0.55 & 1.25 & 2.16 & 0.072 & 13.02 \\
\hline 13 & $33 X-4,40-42$ & 292.80 & 64.33 & 0.29 & 8.38 & 3.05 & 3.17 & 2.44 & 1.28 & 1.16 & 1.59 & 0.078 & 14.23 \\
\hline 14 & $36 X-2,41-43$ & 318.81 & 69.95 & 0.15 & 6.31 & 1.83 & 2.20 & 1.27 & 2.11 & 0.90 & 0.90 & 0.068 & 14.33 \\
\hline 15 & $36 \times-5,41-43$ & 323.31 & 73.12 & 0.25 & 8.11 & 2.88 & 0.34 & 1.51 & 0.37 & 1.23 & 1.77 & 0.054 & 10.39 \\
\hline 16 & $38 X-4,38-40$ & 341.08 & 71.74 & 0.31 & 8.50 & 3.38 & 0.13 & 2.03 & 0.22 & 0.74 & 1.68 & 0.053 & 11.21 \\
\hline 17 & $38 X-6,39-40$ & 344.09 & 63.98 & 0.39 & 11.13 & 4.93 & 0.24 & 2.92 & 0.31 & 1.52 & 2.56 & 0.054 & 11.96 \\
\hline 18 & $42 X-4,40-42$ & 379.90 & 51.16 & 0.43 & 10.10 & 4.60 & 6.17 & 4.34 & 3.07 & 1.09 & 2.22 & 0.126 & 16.69 \\
\hline 19 & $45 X-4,40-42$ & 408.80 & 64.26 & 0.43 & 10.59 & 4.44 & 0.66 & 3.25 & 0.57 & 1.13 & 2.23 & 0.072 & 12.36 \\
\hline 20 & $49 X-1,40-42$ & 443.00 & 54.26 & 0.65 & 14.74 & 6.22 & 1.88 & 3.08 & 1.22 & 1.18 & 3.14 & 0.123 & 13.50 \\
\hline 21 & $799 \mathrm{~B}-6 \mathrm{R}-1,40-42$ & 495.00 & 56.37 & 0.48 & 12.37 & 5.51 & 0.17 & 2.56 & 1.10 & 1.09 & 2.43 & 0.092 & 17.83 \\
\hline 22 & $7 R-4,32-34$ & 504.52 & 56.59 & 0.43 & 11.03 & 4.57 & 2.19 & 2.69 & 2.50 & 1.04 & 2.18 & 0.161 & 16.61 \\
\hline 23 & $12 \mathrm{R}-1,125-127$ & 549.15 & 59.11 & 0.39 & 10.22 & 4.91 & 1.30 & 2.89 & 1.20 & 0.83 & 2.02 & 0.084 & 17.06 \\
\hline 24 & $12 R-3,40-42$ & 551.30 & 62.16 & 0.45 & 11.36 & 4.83 & 0.15 & 2.40 & 0.40 & 0.84 & 2.26 & 0.096 & 15.03 \\
\hline 25 & $15 R-1,40-42$ & 577.40 & 59.70 & 0.43 & 11.80 & 5.53 & 0.30 & 2.00 & 0.52 & 0.88 & 2.17 & 0.102 & 16.56 \\
\hline 26 & $17 \mathrm{R}-1,93-95$ & 597.23 & 13.07 & 0.04 & 3.78 & 6.20 & 18.03 & 4.63 & 10.44 & 0.10 & 0.19 & 0.226 & 43.30 \\
\hline 27 & $18 \mathrm{R}-2,40-41$ & 607.80 & & & & & & & & & & & \\
\hline 28 & $20 \mathrm{R}-7,30-32$ & 634.50 & 56.55 & 0.31 & 9.49 & 5.45 & 6.98 & 2.63 & 3.02 & 0.77 & 1.85 & 0.144 & 12.81 \\
\hline 29 & $24 R-3,114-116$ & 667.94 & 65.63 & 0.42 & 11.19 & 4.27 & 0.74 & 3.50 & 0.61 & 0.98 & 2.51 & 0.082 & 10.08 \\
\hline 30 & $27 R-1,40-42$ & 692.90 & 56.37 & 0.56 & 13.65 & 5.51 & 1.68 & 3.93 & 1.10 & 0.97 & 2.98 & 0.200 & 13.03 \\
\hline 31 & $29 \mathrm{R}-3,50-52$ & 715.30 & 66.30 & 0.48 & 11.59 & 4.37 & 0.62 & 2.79 & 0.61 & 0.90 & 2.45 & 0.102 & 9.81 \\
\hline 32 & $29 \mathrm{R}-4,50-52$ & 716.80 & 67.17 & 0.41 & 10.78 & 3.81 & 0.95 & 2.63 & 0.70 & 0.91 & 2.15 & 0.101 & 10.40 \\
\hline 33 & $29 R-7,50-52$ & 721.30 & 67.52 & 0.41 & 10.28 & 3.61 & 0.26 & 2.15 & 0.39 & 0.89 & 2.02 & 0.098 & 12.38 \\
\hline 34 & $30 \mathrm{R}-1,49-52$ & 721.89 & & & & & & & & & & & \\
\hline 35 & $34 \mathrm{R}-2,40-42$ & 761.70 & & & & & & & & & & & \\
\hline 36 & ${ }^{3} 3 \mathrm{R}-2,44-50$ & 761.74 & 75.56 & 0.24 & 7.55 & 2.62 & 1.04 & 0.96 & 0.63 & 0.59 & 1.05 & 0.080 & 9.68 \\
\hline 37 & ${ }^{\prime} 34 \mathrm{R}-2,44-50$ & 761.74 & 79.78 & 0.21 & 7.23 & 1.96 & 0.16 & 0.77 & 0.29 & 0.63 & 0.96 & 0.074 & 7.95 \\
\hline 38 & $35 R-1,1-3$ & 769.51 & & & & & & & & & & & \\
\hline 39 & $35 \mathrm{R}-1,107-113$ & 770.57 & 82.19 & 0.20 & 4.94 & 2.15 & 0.10 & 0.78 & 0.25 & 0.84 & 0.96 & 0.075 & 7.5 \\
\hline 40 & ${ }^{d} 35 \mathrm{R}-1,107-113$ & 770.57 & 14.23 & 0.01 & 3.45 & 0.86 & 2.41 & 16.10 & 22.72 & 0.08 & 0.06 & 0.101 & 39.97 \\
\hline 41 & $41 \mathrm{R}-1,40-42$ & 827.50 & 68.15 & 0.45 & 12.24 & 1.58 & 0.04 & 3.29 & 0.31 & 1.36 & 0.24 & 0.061 & 12.27 \\
\hline 42 & $46 \mathrm{R}-3,50-52$ & 878.80 & 79.72 & 0.24 & 7.68 & 1.96 & 0.04 & 1.01 & 0.24 & 0.33 & 1.37 & 0.082 & 7.35 \\
\hline 43 & $47 R-3,52-54$ & 888.52 & 73.81 & 0.35 & 9.25 & 2.85 & 0.24 & 1.72 & 0.36 & 5.47 & 1.95 & 0.119 & 8.80 \\
\hline 44 & $49 \mathrm{R}-2,19-21$ & 905.89 & 67.13 & 0.36 & 12.73 & 2.90 & 0.11 & 2.64 & 0.69 & 1.73 & 1.84 & 0.136 & 9.71 \\
\hline 45 & $51 \mathrm{R}-1,39-41$ & 923.69 & & & & & & & & & & & \\
\hline 46 & '53R-1, 46-48 & 943.06 & 75.5 & 0.29 & 8.46 & 2.66 & 0.73 & 1.65 & 0.84 & 0.74 & 1.49 & 0.093 & 7.50 \\
\hline 47 & $f_{53 R-1,46-48}$ & 943.06 & 77.61 & 0.28 & 8.22 & 2.33 & 0.26 & 1.34 & 0.43 & 0.68 & 1.46 & 0.092 & 7.31 \\
\hline 48 & $56 \mathrm{R}-1,36-38$ & 971.86 & & & & & & & & & & & \\
\hline 49 & $56 \mathrm{R}-3,49-51$ & 974.99 & 58.64 & 0.54 & 12.42 & 6.24 & 0.29 & 2.24 & 0.80 & 1.48 & 3.63 & 0.177 & 13.54 \\
\hline 50 & $57 \mathrm{R}-1,40-42$ & 981.50 & 65.71 & 0.23 & 11.84 & 3.87 & 1.33 & 1.61 & 0.90 & 0.73 & 3.48 & 0.100 & 10.20 \\
\hline 51 & $59 \mathrm{R}-1,38-40$ & 1000.88 & & & & & & & & & & & \\
\hline 52 & $60 \mathrm{R}-3,45-47$ & 1013.65 & 69.08 & 0.47 & 10.40 & 4.14 & 0.07 & 1.68 & 0.51 & 1.08 & 1.90 & 0.181 & 10.51 \\
\hline 53 & $61 \mathrm{R}-2,49-52$ & 1021.79 & 70.71 & 0.36 & 12.42 & 2.80 & 0.16 & 1.40 & 1.04 & 2.32 & 2.61 & 0.131 & 6.05 \\
\hline 54 & $61 \mathrm{R}-5,100-102$ & 1026.80 & 72.95 & 0.35 & 9.17 & 2.87 & 0.33 & 1.48 & 0.63 & 1.00 & 1.52 & 0.117 & 9.57 \\
\hline 55 & ${ }^{8} 61 R-6,52-55$ & 1027.82 & 71.33 & 0.32 & 8.68 & 3.03 & 1,17 & 1.51 & 1.25 & 0.86 & 1.43 & 0.180 & 10.22 \\
\hline 56 & h $61 \mathrm{R}-6,52-55$ & 1027.82 & 69.11 & 0.12 & 6.48 & 1.50 & 4.12 & 1.05 & 5.93 & 0.50 & 0.62 & 0.138 & 10.45 \\
\hline 57 & $62 \mathrm{R}-3,15-17$ & 1032.65 & 9.90 & 0.05 & 1.61 & 2.63 & 4.46 & 15.84 & 25.96 & 0.18 & 0.31 & 0.070 & 38.98 \\
\hline 58 & $63 R-3,18-20$ & 1042.28 & 63.06 & 0.43 & 10.59 & 4.33 & 1.30 & 2.13 & 2.22 & 1.10 & 1.81 & 0.207 & 12.82 \\
\hline
\end{tabular}

${ }^{\text {a }}$ Total iron as $\mathrm{Fe}_{2} \mathrm{O}_{3}$.

${ }^{\mathrm{b}}$ Darker portion.

${ }^{c}$ Lighter portion.

${ }^{\mathrm{A}}$ Dolomite concretion.

e Top of the interval,

${ }^{f}$ Bottom of the interval.

${ }^{g}$ Darker portion.

${ }^{\text {h }}$ Lighter portion.

hydrogenous manganese precipitation. Besides, in a seawater column it has been reported (Elderfield and Sholkovitz, 1987; German and Elderfield, 1989, 1990) that the profile of cerium is similar to that of manganese because the oxidation-reduction potential of manganese (IV) is identical to the potential of cerium (IV) oxides (Leinen, 1977). It has been recognized that manganese in marine sediments is mainly supplied by hydrogenous precipitation (e.g., Matsumoto et al., 1985).
The association of cerium with manganese in marine environments and the similarity of these elements in oxidation-reduction chemistry suggest that the positive cerium anomaly observed in the REE patterns of the samples at Site 799 indicates a contribution of hydrogenous manganese precipitation to the sediment. However, $\mathrm{MnO}$ content in the sediments does not correlate well with positive cerium anomaly, as shown in Figure 14. It is notable that manganese 
Table 4. Trace element concentrations in the sediments from Site 799.

\begin{tabular}{|c|c|c|c|c|c|c|c|c|c|c|c|c|c|c|c|}
\hline $\begin{array}{c}\text { Sample } \\
\text { no. }\end{array}$ & $\begin{array}{l}\text { Core, section, } \\
\text { interval }(\mathrm{cm})\end{array}$ & $\begin{array}{l}\text { Depth } \\
\text { (mbsf) }\end{array}$ & $\begin{array}{c}\text { As } \\
(\mathrm{ppm})\end{array}$ & $\underset{(\mathrm{ppm})}{\mathrm{Ba}}$ & $\begin{array}{c}\mathrm{Br} \\
\text { (ppm) }\end{array}$ & $\begin{array}{c}\text { Co } \\
(\mathrm{ppm})\end{array}$ & $\underset{(\mathrm{ppm})}{\mathrm{Cr}}$ & $\begin{array}{c}\text { Cs } \\
(\mathrm{ppm})\end{array}$ & $\begin{array}{c}\mathrm{Hf} \\
(\mathrm{ppm})\end{array}$ & $\underset{(\mathrm{ppm})}{\mathrm{Sb}}$ & $\underset{(\mathrm{ppm})}{\mathrm{Sc}}$ & $\begin{array}{c}\mathrm{Ta} \\
(\mathrm{ppm})\end{array}$ & $\begin{array}{c}\text { Th } \\
\text { (ppm) }\end{array}$ & $\underset{\text { (ppm) }}{\mathrm{U}}$ & $\begin{array}{c}\mathrm{La} \\
\text { (ppm) }\end{array}$ \\
\hline 1 & 799A-3H-4, 41-43 & 15.61 & 14 & 750 & 24 & 22 & 62 & 7.8 & 4.4 & 2.5 & 15 & 1.5 & 14 & 4.7 & 39 \\
\hline 2 & $6 \mathrm{H}-2,44-46$ & 41.44 & 5 & 840 & 40 & 21 & 56 & 3.5 & 5.5 & 2.4 & 14 & 2.4 & 14 & 3.8 & 43 \\
\hline 3 & $9 \mathrm{H}-2,36-38$ & 70.16 & 10 & 871 & 32 & 26 & 49 & 5.3 & 3.7 & 4.0 & 10 & 1.9 & 10 & 6.2 & 35 \\
\hline 4 & $9 \mathrm{H}-2,133-135$ & 71.13 & 3 & 540 & 19 & 8 & 11 & 1.5 & 2.4 & 1.5 & 4 & 1.1 & 8 & 5.6 & 28 \\
\hline 5 & $12 \mathrm{H}-6,43-45$ & 105.63 & 2 & 1290 & 40 & 29 & 56 & 6.6 & 2.5 & 3.5 & 13 & 1.0 & 12 & 2.3 & 32 \\
\hline 6 & $15 \mathrm{H}-2,39-41$ & 127.99 & 2 & 1940 & 26 & 44 & 63 & 8.1 & 3.9 & 4.8 & 15 & 1.4 & 14 & 1.7 & 34 \\
\hline 7 & $18 \mathrm{H}-5,40-42$ & 161.60 & 1 & 3100 & 52 & 39 & 44 & 4.8 & 2.7 & 5.0 & 12 & 0.8 & 10 & 2.3 & 26 \\
\hline 8 & $22 X-1,91-93$ & 194.71 & 4 & 3250 & 59 & 50 & 51 & 6.3 & 3.2 & 8.9 & 14 & 1.0 & 12 & 3.1 & 36 \\
\hline 9 & $24 X-2,40-42$ & 215.00 & 4 & 4000 & 41 & 64 & 51 & 6.8 & 3.2 & 8.7 & 13 & 0.8 & 12 & 5.3 & 35 \\
\hline 10 & $25 X-2,41-43$ & 224.71 & 5 & 3728 & 41 & 24 & 27 & 3.4 & 1.7 & 3.2 & 6 & 0.8 & 5 & 5.4 & 36 \\
\hline 11 & $27 \mathrm{X}-3,126-128$ & 245.66 & 4 & 3130 & 26 & 34 & 22 & 2.5 & 1.4 & 3.7 & 6 & 0.6 & 5 & 6.6 & 20 \\
\hline 12 & $30 X-2,40-42$ & 262.40 & 4 & 3300 & 63 & 60 & 40 & 4.9 & 2.5 & 9.9 & 12 & 0.8 & 9 & 4.7 & 24 \\
\hline 13 & $33 X-4,40-42$ & 292,80 & 2 & 3310 & 44 & 49 & 28 & 3.6 & 1.9 & 4.3 & 9 & 0.6 & 6 & 2.8 & 20 \\
\hline 14 & $36 X-2,41-43$ & 318.81 & 2 & 1220 & 39 & 33 & 18 & 1.9 & 1.1 & 3.6 & 5 & 0.4 & 4 & 4.4 & 13 \\
\hline 15 & $36 X-5,41-43$ & 323.31 & 4 & 1184 & 17 & 24 & 24 & 3.8 & 6.2 & 2.8 & 7 & 4.2 & 12 & 5.9 & 34 \\
\hline 16 & $38 X-4,38-40$ & 341.08 & 6 & 1721 & 28 & 22 & 34 & 4 & 1.8 & 3.9 & 8 & 0.9 & 6 & 4.2 & 18 \\
\hline 17 & $38 \times-6,39-40$ & 344.09 & 1 & 2990 & 31 & 41 & 41 & 7.9 & 4.6 & 4.2 & 12 & 5.7 & 20 & 6.8 & 27 \\
\hline 18 & $42 X-4,40-42$ & 379.90 & 4 & 2340 & 47 & 42 & 44 & 5.4 & 2.6 & 8.6 & 12 & 0.9 & 9 & 4.6 & 29 \\
\hline 19 & $45 X-4,40-42$ & 408.80 & 1 & 2140 & 34 & 36 & 45 & 5.6 & 2.4 & 3.9 & 12 & 0.9 & 9 & 2.1 & 25 \\
\hline 20 & $49 X-1,40-42$ & 443.00 & 6 & 2370 & 48 & 41 & 44 & 5.3 & 2.2 & 5.1 & 12 & 0.9 & 9 & 5.0 & 26 \\
\hline 21 & $799 \mathrm{~B}-6 \mathrm{R}-1,40-42$ & 495.00 & 2 & 2430 & 68 & 60 & 76 & 6.3 & 3.1 & 9.1 & 15 & 0.8 & 11 & 4.5 & 36 \\
\hline 22 & $7 \mathrm{R}-4,32-34$ & 504.52 & 3 & 1960 & 36 & 39 & 52 & 5.5 & 2.2 & 6.5 & 11 & 0.9 & 10 & 3.0 & 25 \\
\hline 23 & $12 \mathrm{R}-1,125-127$ & 549.15 & 7 & 1200 & 24 & 64 & 45 & 5.2 & 2.2 & 9.3 & 11 & 0.6 & 9 & 5.5 & 29 \\
\hline 24 & $12 \mathrm{R}-3,40-42$ & 551.30 & 9 & 1380 & 49 & 44 & 74 & 5.9 & 2.7 & 7.2 & 13 & 1.2 & 9 & 7.0 & 36 \\
\hline 25 & $15 R-1,40-42$ & 577.40 & 7 & 1040 & 35 & 88 & 65 & 5.3 & 2.6 & 12.9 & 13 & 1.3 & 10 & 7.9 & 34 \\
\hline 26 & 17R-1,93-95 & 597.23 & 5 & 910 & 10 & 19 & 8 & 0.8 & 0.6 & 1.5 & 5 & 0.2 & 2 & 4.4 & 11 \\
\hline 27 & $18 \mathrm{R}-2,40-41$ & 607.80 & 3 & 1160 & 21 & 45 & 48 & 5.1 & 2.5 & 5.6 & 13 & 1.1 & 10 & 5.4 & 27 \\
\hline 28 & $20 \mathrm{R}-7,30-32$ & 634.50 & 7 & 690 & 13 & 55 & 24 & 3.9 & 2.2 & 1.8 & 7 & 1.1 & 7 & 3.7 & 22 \\
\hline 29 & $24 \mathrm{R}-3,114-116$ & 667.94 & 3 & 1310 & 5 & 37 & 39 & 5.5 & 3.2 & 3.1 & 14 & 1.2 & 10 & 3.8 & 29 \\
\hline 30 & $27 \mathrm{R}-1,40-42$ & 692.90 & 4 & 950 & 7 & 41 & 50 & 7 & 3.2 & 5.2 & 17 & 1.4 & 13 & 5.3 & 37 \\
\hline 31 & $29 \mathrm{R}-3,50-52$ & 715.30 & 7 & 1076 & 11 & 22 & 54 & 5.5 & 3 & 2.4 & 14 & 1 & 9 & 5.4 & 26 \\
\hline 32 & $29 \mathrm{R}-4,50-52$ & 716.80 & 7 & 2850 & 10 & 26 & 40 & 4.8 & 2.7 & 2.8 & 14 & 0.8 & 9 & 7.4 & 23 \\
\hline 33 & $29 \mathrm{R}-7,50-52$ & 721.30 & 7 & 1120 & 8 & 28 & 36 & 5.2 & 2.6 & 2.3 & 13 & 1 & 9 & 6.9 & 23 \\
\hline 34 & $30 \mathrm{R}-1,49-52$ & 721.89 & 4 & 1420 & 8 & 24 & 35 & 4.2 & 2.4 & 2.2 & 14 & 0.9 & 7 & 23.2 & 28 \\
\hline 35 & $34 \mathrm{R}-2,40-42$ & 761.70 & 3 & 930 & 8 & 19 & 27 & 2 & 1.4 & 2.1 & 8 & 0.5 & 5 & 9.0 & 18 \\
\hline 36 & $34 \mathrm{R}-2,44-50$ & 761.74 & 8 & 939 & 9 & 25 & 31 & 2.2 & 1.7 & 2.3 & 8 & 0.4 & 4 & 8.4 & 24 \\
\hline 37 & b $34 \mathrm{R}-2,44-50$ & 761.74 & 7 & 969 & 9 & 10 & 28 & 1.8 & 1.5 & 1.8 & 7 & 0.5 & 4 & 5.2 & 12 \\
\hline 38 & $35 R-1,1-3$ & 769.51 & 1 & 194 & 4 & 3 & 5 & 0.3 & 0.2 & 0.3 & 1 & 0.1 & 1 & 1.7 & 4 \\
\hline 39 & $35 \mathrm{R}-1,107-113$ & 770.57 & 6 & 1072 & 12 & 14 & 27 & 1.8 & 1.6 & 1.9 & 6 & 0.5 & 4 & 5.2 & 18 \\
\hline 40 & ${ }^{c} 35 \mathrm{R}-1,107-113$ & 770.57 & & & & & & & & & & & & & \\
\hline 41 & $41 \mathrm{R}-1,40-42$ & 827.50 & 4 & 600 & 1 & 3 & 4 & 1.3 & 5.4 & 0.9 & 10 & 1.1 & 15 & 5.9 & 34 \\
\hline 42 & $46 \mathrm{R}-3,50-52$ & 878.80 & 5 & 680 & 8 & 6 & 28 & 2.7 & 1.4 & 2 & 7 & 0.6 & 4 & 3.8 & 14 \\
\hline 43 & $47 \mathrm{R}-3,52-54$ & 888.52 & 4 & 590 & 6 & 19 & 37 & 3.6 & 2.1 & 3.1 & 10 & 0.7 & 6 & 6.5 & 19 \\
\hline 44 & $49 \mathrm{R}-2,19-21$ & 905.89 & 2 & 650 & 4 & 1 & 22 & 2.9 & 5.3 & 2.1 & 11 & 1 & 7 & 4.9 & 20 \\
\hline 45 & $51 \mathrm{R}-1,39-41$ & 923.69 & 4 & 510 & 4 & 19 & 31 & 3.6 & 1.6 & 3.1 & 9 & 0.6 & 6 & 3.9 & 17 \\
\hline 46 & ${ }^{\mathrm{d}} 53 \mathrm{R}-1,46-48$ & 943.06 & 5 & 620 & 3 & 24 & 27 & 2.9 & 1.9 & 3.6 & 7 & 0.5 & 6 & 4.2 & 15 \\
\hline 47 & ${ }^{2} 53 \mathrm{R}-1,46-48$ & 943.06 & 4 & 640 & 4 & 17 & 26 & 2.6 & 1.7 & 3.3 & 6 & 0.7 & 5 & 3.5 & 14 \\
\hline 48 & $56 \mathrm{R}-1,36-38$ & 971.86 & 5 & 520 & 4 & 22 & 34 & 3,1 & 2.3 & 3.3 & 9 & 0.7 & 6 & 3.3 & 28 \\
\hline 49 & $56 \mathrm{R}-3,49-51$ & 974.99 & 13 & 644 & 9 & 23 & 60 & 5.1 & 3 & 6.9 & 13 & 1 & 9 & 4.2 & 24 \\
\hline 50 & $57 \mathrm{R}-1,40-42$ & 981.50 & 54 & 1664 & 4 & 10 & 17 & 2.9 & 2.7 & 3.5 & 6 & 1.1 & 11 & 4.9 & 27 \\
\hline 51 & $59 \mathrm{R}-1,38-40$ & 1000.88 & 3 & 470 & 1 & 3 & 11 & 2.6 & 4.6 & 0.8 & 9 & 2.2 & 25 & 6.4 & 50 \\
\hline 52 & $60 \mathrm{R}-3,45-47$ & 1013.65 & 9 & 393 & 7 & 12 & 48 & 3.9 & 2.8 & 2 & 10 & 0.9 & 7 & 7.0 & 22 \\
\hline 53 & $61 \mathrm{R}-2,49-52$ & 1021.79 & 4 & 550 & 3 & 9 & 26 & 2.5 & 4 & 1.4 & 8 & 0.8 & 5 & 4.9 & 17 \\
\hline 54 & $61 \mathrm{R}-5,100-102$ & 1026.80 & 4 & 270 & 5 & 21 & 39 & 3.3 & 2.3 & 2.3 & 10 & 0.7 & 7 & 5.4 & 18 \\
\hline 55 & ${ }^{\mathrm{f}} 61 \mathrm{R}-6,52-55$ & 1027.82 & 6 & 353 & 6 & 20 & 37 & 3 & 2.2 & 2.7 & 8 & 0.6 & 6 & 3.8 & 20 \\
\hline 56 & $861 \mathrm{R}-6,52-55$ & 1027.82 & 3 & 412 & 4 & 13 & 18 & 1.2 & 1 & 1.5 & 6 & 0.2 & 3 & 4.3 & 12 \\
\hline 57 & $62 R-3,15-17$ & 1032.65 & 1 & 268 & 2 & 5 & 8 & 0.7 & 0.5 & 0.6 & 2 & 0.1 & 1 & 0.8 & 5 \\
\hline 58 & $63 R-3,18-20$ & 1042.28 & 7 & 447 & 7 & 39 & 51 & 4 & 2.9 & 3.5 & 12 & 0.8 & 7 & 3.5 & 29 \\
\hline
\end{tabular}

a Darker portion.

${ }^{b}$ Lighter portion.

${ }^{c}$ Dolomite concretion.

Top of the interval.

${ }^{c}$ Bottom of the interval.

${ }^{\mathrm{f}}$ Darker portion.

${ }^{g}$ Lighter portion.

carbonates occurred at the ODP sites in the Japan Sea (Matsumoto, this volume). Manganese oxide precipitation and diagenetic transformation in the sediment column are regarded as important processes in the formation of manganese carbonate concretions (Matsumoto, this volume). Manganese content is primarily dependent on the amounts of manganese carbonates in the sediments from Site 799. In the process of formation of manganese carbonates in the sediment column, man- ganese (IV) is reduced to manganese (II), which is more mobile than manganese (IV) because of its higher solubility into pore water. Tetravalent cerium can be reduced to the lower oxidation state, trivalent cerium, during reduction of manganese (IV) in the diagenetic processes. Differences in the oxidation state after reduction (manganese (II) and cerium (III)) can lead to fractionation of cerium from manganese after burial and the formation of manganese-bearing carbonates with- 
Table 4 (continued).

\begin{tabular}{|c|c|c|c|c|c|c|}
\hline $\begin{array}{c}\text { Sample } \\
\text { no. }\end{array}$ & $\underset{(\mathrm{ppm})}{\mathrm{Ce}}$ & $\underset{(\mathrm{ppm})}{\mathrm{Sm}}$ & $\begin{array}{c}\mathrm{Eu} \\
(\mathrm{ppm})\end{array}$ & $\begin{array}{c}\mathrm{Tb} \\
(\mathrm{ppm})\end{array}$ & $\begin{array}{c}\mathrm{Yb} \\
(\mathrm{ppm})\end{array}$ & $\underset{(\mathrm{ppm})}{\mathrm{Lu}}$ \\
\hline 1 & 81 & 7.2 & 1.4 & 0.95 & 3.2 & 0.55 \\
\hline 2 & 95 & 7.5 & 1.2 & 0.78 & 3.0 & 0.41 \\
\hline 3 & 66 & 6.1 & 1.1 & 0.82 & 2.6 & 0.38 \\
\hline 4 & 66 & 4.8 & 0.8 & 0.80 & 2.3 & 0.34 \\
\hline 5 & 71 & 6.6 & 1.4 & 1.00 & 3.2 & 0.42 \\
\hline 6 & 83 & 6.6 & 1.3 & 0.93 & 3.5 & 0.50 \\
\hline 7 & 81 & 4.9 & 1.0 & 0.69 & 1.9 & 0.28 \\
\hline 8 & 90 & 8.0 & 1.7 & 1.05 & 4.0 & 0.57 \\
\hline 9 & 91 & 7.2 & 1.4 & 1.26 & 3.8 & 0.54 \\
\hline 10 & 37 & 6.4 & 0.6 & 0.43 & 1.1 & 0.39 \\
\hline 11 & 48 & 4.8 & 1.0 & 1.12 & 4.1 & 0.71 \\
\hline 12 & 73 & 5.7 & 1.2 & 0.80 & 2.5 & 0.43 \\
\hline 13 & 57 & 5.1 & 1.0 & 0.85 & 3.7 & 0.55 \\
\hline 14 & 40 & 2.9 & 0.6 & 0.65 & 2.2 & 0.30 \\
\hline 15 & 72 & 6.0 & 0.6 & 0.90 & 3.1 & 0.60 \\
\hline 16 & 43 & 3.6 & 0.7 & 0.50 & 1.1 & 0.27 \\
\hline 17 & 75 & 5.2 & 0.9 & 0.96 & 3.9 & 0.54 \\
\hline 18 & 75 & 5.9 & 1.2 & 0.88 & 4.0 & 0.50 \\
\hline 19 & 73 & 5.6 & 1.1 & 0.62 & 2.9 & 0.40 \\
\hline 20 & 80 & 5.5 & 1.1 & 0.59 & 2.3 & 0.31 \\
\hline 21 & 62 & 8.1 & 1.6 & 0.87 & 4.0 & 0.50 \\
\hline 22 & 75 & 5.1 & 1.1 & 0.79 & 2.9 & 0.34 \\
\hline 23 & 80 & 6.5 & 1.3 & 1.10 & 3.9 & 0.57 \\
\hline 24 & 82 & 7.0 & 1.3 & 1.04 & 2.0 & 0.59 \\
\hline 25 & 108 & 7.8 & 1.5 & 1.02 & 2.7 & 0.50 \\
\hline 26 & 36 & 2.8 & 0.6 & 0.65 & 2.4 & 0.47 \\
\hline 27 & 97 & 6.5 & 1.9 & 1.12 & 3.2 & 0.52 \\
\hline 28 & 65 & 4.8 & 0.9 & 0.89 & 2.4 & 0.45 \\
\hline 29 & 91 & 6.3 & 1.6 & 0.99 & 2.7 & 0.45 \\
\hline 30 & 121 & 8.9 & 1.7 & 1.22 & 3.7 & 0.49 \\
\hline 31 & 71 & 5.4 & 1.0 & 0.80 & 2.3 & 0.43 \\
\hline 32 & 74 & 5.8 & 1.1 & 0.98 & 2.4 & 0.46 \\
\hline 33 & 68 & 5.7 & 1.0 & 0.60 & 2.0 & 0.42 \\
\hline 34 & 85 & 5.6 & 1.4 & 0.94 & 3.9 & 0.71 \\
\hline 35 & 49 & 4.8 & 1.4 & 0.76 & 1.7 & 0.38 \\
\hline 36 & 66 & 6.9 & 1.4 & 1.09 & 2.7 & 0.74 \\
\hline 37 & 28 & 2.6 & 0.5 & 0.37 & 1.0 & 0.24 \\
\hline 38 & 7 & 0.9 & 0.2 & 0.13 & 0.5 & 0.14 \\
\hline 39 & 41 & 4.3 & 0.8 & 0.61 & 1.7 & 0.42 \\
\hline \multicolumn{7}{|l|}{40} \\
\hline 41 & 78 & 6.9 & 1.1 & 1.11 & 2.8 & 0.44 \\
\hline 42 & 27 & 2.7 & 0.5 & 0.33 & 1.2 & 0.31 \\
\hline 43 & 46 & 4.6 & 0.9 & 0.74 & 2.0 & 0.40 \\
\hline 44 & 47 & 4.6 & 1.3 & 0.87 & 2.9 & 0.45 \\
\hline 45 & 41 & 3.8 & 1.0 & 0.53 & 1.9 & 0.31 \\
\hline 46 & 39 & 3.5 & 0.6 & 0.70 & 1.3 & 0.27 \\
\hline 47 & 37 & 3.2 & 0.6 & 0.44 & 1.3 & 0.26 \\
\hline 48 & 46 & 4.0 & 1.2 & 0.76 & 1.9 & 0.31 \\
\hline 49 & 54 & 4.4 & 0.9 & 0.57 & 2.4 & 0.67 \\
\hline 50 & 55 & 6.5 & 0.7 & 1.04 & 3.5 & 0.95 \\
\hline 51 & 114 & 10.0 & 0.8 & 1.98 & 5.3 & 0.80 \\
\hline 52 & 47 & 4.7 & 0.9 & 0.70 & 2.4 & 0.53 \\
\hline 53 & 39 & 3.8 & 1.0 & 0.63 & 1.8 & 0.27 \\
\hline 54 & 49 & 4.3 & 0.8 & 0.87 & 2.1 & 0.34 \\
\hline 55 & 46 & 4.0 & 0.8 & 0.57 & 1.9 & 0.39 \\
\hline 56 & 27 & 2.6 & 0.5 & 0.37 & 1.4 & 0.26 \\
\hline 57 & 10 & 0.9 & 0.2 & 0.15 & 0.4 & 0.13 \\
\hline 58 & 64 & 5.6 & 1.1 & 0.70 & 2.6 & 0.60 \\
\hline
\end{tabular}

out cerium enrichment. The possible reduction of cerium to the trivalent state implies that cerium behaves as an ordinary trivalent REE in the sediment column after reduction in diagenesis. Hence, it can be expected that the degree of the cerium anomaly did not change after burial, although the $\mathrm{MnO}$ content changed in diagenetic processes after reduction. Also, it is noteworthy that the degree of positive cerium anomaly could be a measure for estimating the amount of hydrogenous precipitation correlating to manganese influx at sedimentation even if the $\mathrm{MnO}$ content changed in diagenesis after burial.

The depth profile of the $\mathrm{Ce} / \mathrm{Ce}$ * ratio in sediments from Site 799 (Fig. 13B) shows that degree of positive cerium anomaly is relatively high in the 200-750 mbsf range. We can expect that the rate of hydrogenous precipitation of manganese is high in that range. During the sedimentation, terrigenous detritus (without cerium anom- aly) and hydrogenous precipitates of manganese (associated with cerium-enriched REE's) would be deposited on the ocean bottom. However, it is noteworthy that some of the samples (e.g., samples 10 and 21 ) show a negative cerium anomaly $(\mathrm{Ce} / \mathrm{Ce}$ * ratio below 1$)$. Negative cerium anomaly has been reported for seawater (e.g., Goldberg and Arrhenius, 1958; Elderfield and Sholkovitz, 1987: German and Elderfield, 1989, 1990) and for mud, carbonaceous ooze, chert, and fish debris in oceanic environments (e.g., Piper, 1974; Shimizu and Masuda, 1977; Toyoda et al., 1990; Matsumoto et al., 1988; Minai and Tominaga, 1989). Perhaps REE's in seawater with a negative cerium anomaly were transferred to such sediments as they were formed, through adsorption on biogenic materials or hydrogenous precipitation (except for manganese hydroxides carrying REE's with positive cerium anomaly).

It has been claimed that the negative cerium anomaly is a measure of hydrothermal activity, based on comparison of manganese contents, sedimentation rates, and REE patterns of marine sediments (Matsumoto and Minai, 1985; Matsumoto et al., 1985; Minai et al., 1985). At Site 799, it has been reported that the MnO content was strongly changed by diagenetic processes after burial (Matsumoto, this volume). Since we cannot compare the degree of cerium anomaly with $\mathrm{MnO}$ content in the sediment before diagenesis, the negative cerium anomaly observed in some samples cannot be a decisive clue to hydrothermal activity in the Japan Sea.

From the REE patterns and the $\mathrm{Ce} / \mathrm{Ce}$ * ratio, we can assume at least three sources supplying REE's in the sediment column. Terrigenous detritus can be regarded as the major source of REE's in the sediments because the REE patterns of all samples are similar to those of continental crust (showing relative enrichment of LREE to HREE). Hydrogenous precipitates of manganese with positive cerium anomaly can also be regarded as one of the sources because of the positive cerium anomaly frequently observed in the REE patterns of the sediments. Biogenic or hydrogenous precipitates scavenging REE's in seawater with negative cerium anomaly may be the third source of REE's in some sediments at Site 799. It seems that the cerium anomaly could decipher mixing ratios among the materials derived from these sources into the sediments.

Depth profiles of $\mathrm{La} / \mathrm{Yb}$ and $\mathrm{Eu} / \mathrm{Eu}^{*}$ ratios in Figures 12 and 13 may indicate complicated sedimentation processes at Sites 798 and 799. As shown in Fig. 15, the La/Yb (Fig. 15A) and Eu/Eu* (Fig. $15 \mathrm{~B})$ ratios are poorly correlated with the $\mathrm{Ce} / \mathrm{Ce} *$ ratio, which is regarded as an indicator of the mixing proportion of hydrogenous precipitates in the sedimentation. The poor correlation of the $\mathrm{La} / \mathrm{Yb}$ and $\mathrm{Eu} / \mathrm{Eu}^{*}$ ratios with the $\mathrm{Ce} / \mathrm{Ce}$ * ratio suggests that these ratios cannot be regarded as indicators of hydrogenous precipitation. It implies that variations of the $\mathrm{La} / \mathrm{Yb}$ and $\mathrm{Eu} / \mathrm{Eu}^{*}$ ratios in the sediment columns are related to changes of diagenetic processes in the column or mixing ratios among terrigenous sources with different $\mathrm{La} / \mathrm{Yb}$ and $\mathrm{Eu} / \mathrm{Eu} *$ ratios.

In Figure $16, \mathrm{La} / \mathrm{Yb}$ ratio is plotted against $\mathrm{MnO} / \mathrm{Al}_{2} \mathrm{O}_{3}$ ratio. In this plot, $\mathrm{La} / \mathrm{Yb}$ ratio tends to decrease with the increase of the $\mathrm{MnO} / \mathrm{Al}_{2} \mathrm{O}_{3}$ ratio. Usually, $\mathrm{MnO} / \mathrm{Al}_{2} \mathrm{O}_{3}$ ratios are regarded as indicators of hydrogenous contribution to sedimentation since manganese and aluminum are supplied as hydrogenous precipitate and terrigenous detritus, respectively. However, in the sediments from Site 799 , manganese was accumulated after burial at particular layers forming manganese carbonates (Matsumoto, in this volume), whereas aluminum was immobile in the sediment column. Therefore the $\mathrm{MnO} / \mathrm{Al}_{2} \mathrm{O}_{3}$ ratios in the sediments also indicate manganese accumulation by diagenesis.

In Figure 17 dependencies of $\mathrm{La}$ and $\mathrm{Yb}$ concentrations on $\mathrm{Al}_{2} \mathrm{O}_{3}$ content are plotted. Lanthanum and ytterbium represent LREE and HREE, respectively. Concentration of La (Fig. 17A) correlates with $\mathrm{Al}_{2} \mathrm{O}_{3}$ content, as do $\mathrm{TiO}_{2}, \mathrm{Na}_{2} \mathrm{O}, \mathrm{K}_{2} \mathrm{O}, \mathrm{Cr}, \mathrm{Cs}$, $\mathrm{Hf}$, Ta, and Th contents. However, as seen in Figure 17B, the $\mathrm{Yb}$ concentrations, particularly in the sediments from Site 799, are poorly correlated with the $\mathrm{Al}_{2} \mathrm{O}_{3}$ content. As mentioned earlier, terrigenous materials were regarded as 

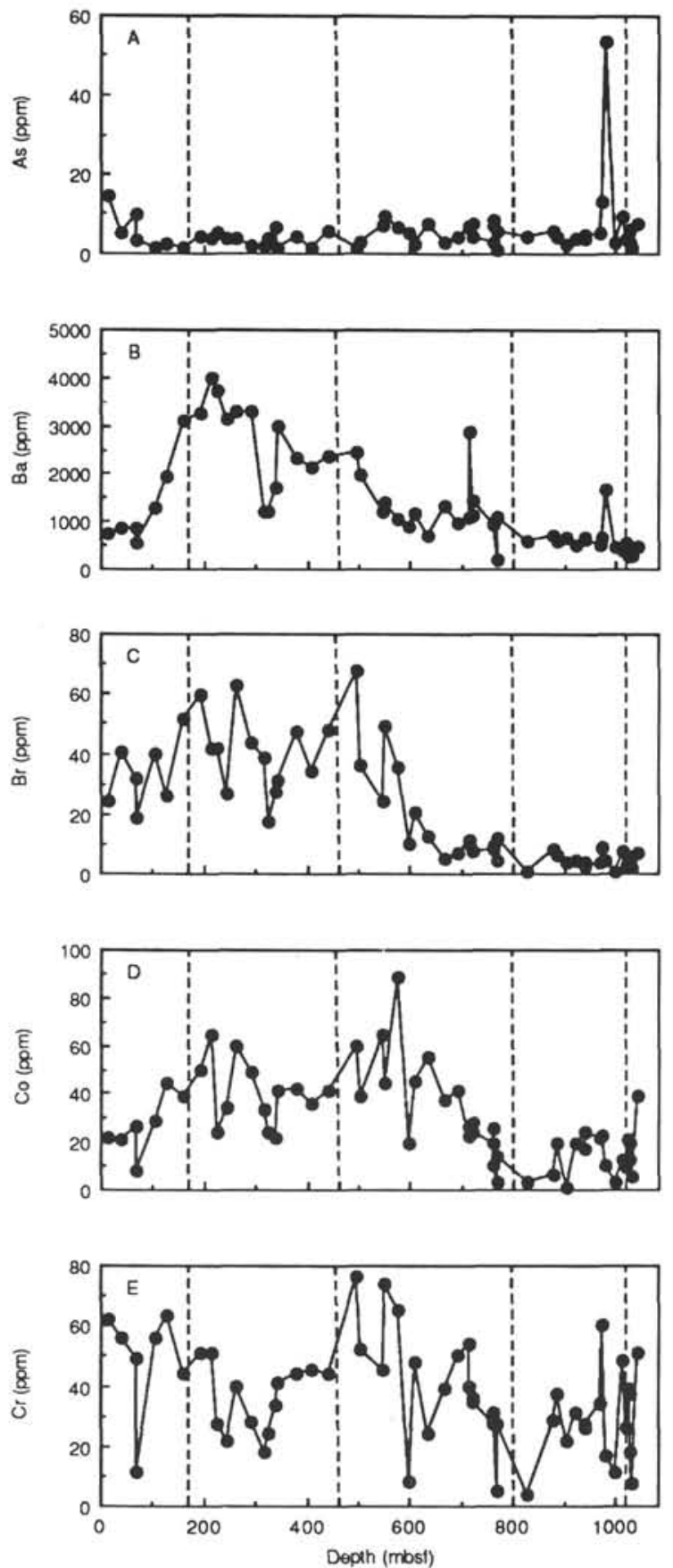
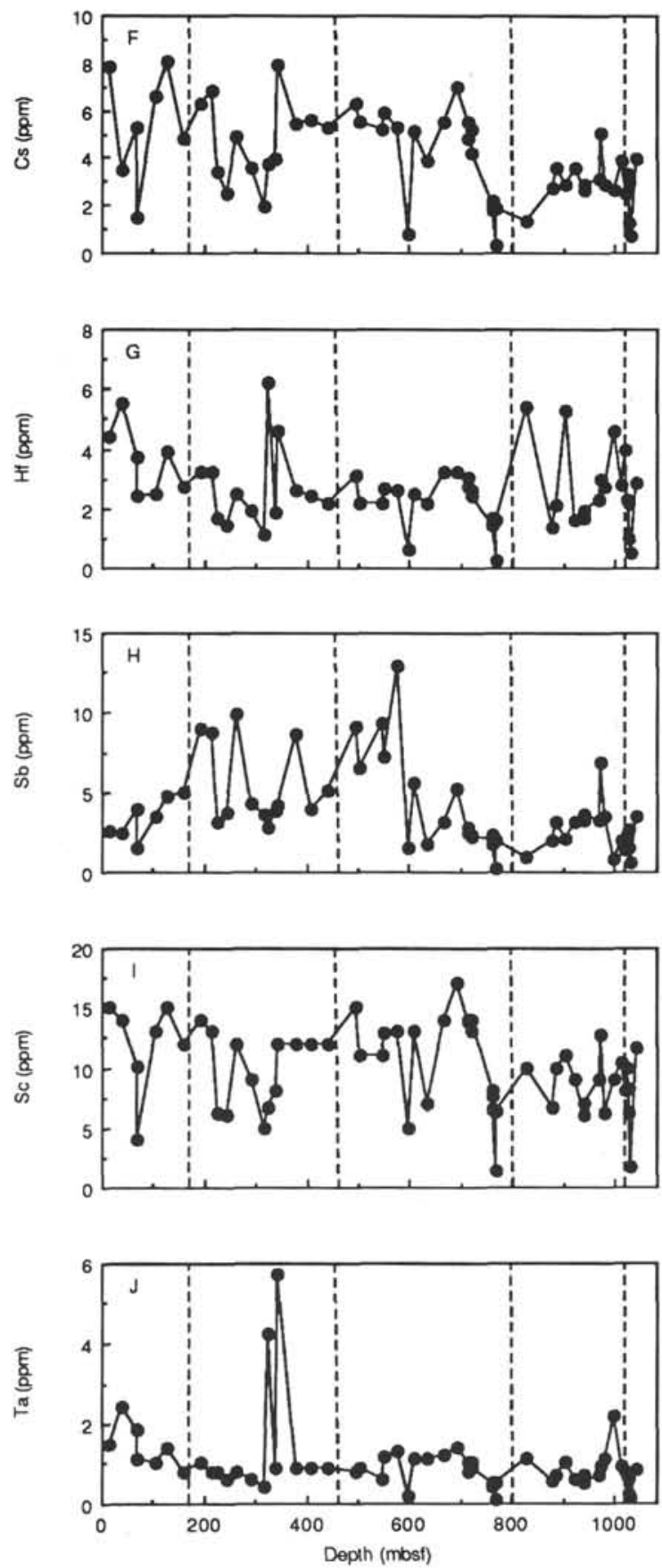

Figure 5. Depth profiles of trace element concentrations (ppm) in the sediments from Site 799: A. As. B. Ba. C. Br. D. Co. E. Cr. F. Cs. G. Hf. H. Sb. I. Sc. J. Ta. K. Th. L. U. M. La. N. Ce. O. Sm. P. Eu. Q. Tb. R. Yb. S. Lu. Broken lines indicate boundaries between lithological units.

a major source of REE in the sediments. Such differences in correlation plot against $\mathrm{Al}_{2} \mathrm{O}_{3}$ content between $\mathrm{La}$ and $\mathrm{Yb}$ concentrations may suggest that source materials with higher HREE concentration were also supplied to the sediment column. Otherwise, differences during diagenesis in geochemical behaviors of LREE and HREE may lead to a discrepancy in the correlation plots against the $\mathrm{Al}_{2} \mathrm{O}_{3}$ content.

It is well recognized that complexation of REE with organic and inorganic ligands depends on the ion radius of REE (Cantrell and Byrne, 1987; Byrne and Kim, 1990). Although dependence of the binding strength of naturally-occurring organic materials on the ion radii is not well understood, HREE with its smaller ion radii tends to bind more strongly with simple organic monocar- boxylates as analogues of the natural organic substances than LREE with its larger ionic radius (Byrne and Kim, 1990). Potentially, complexation with organic substances in the sediments is important in assisting in the dissolution and migration of REE in the sediment column. The stronger binding of HREE than that of LREE with organic materials may lead to higher mobility of HREE accompanied by diagenetic accumulation of manganese, as observed in the sediments from Site 799.

The behavior of REE in diagenesis has been extensively examined in the sediments from Leg 127 (Murray et al., this volume). Although sedimentation environments differed among the sites from Legs 127 and 128 , work on REE geochemistry in the sediments from the ODP 

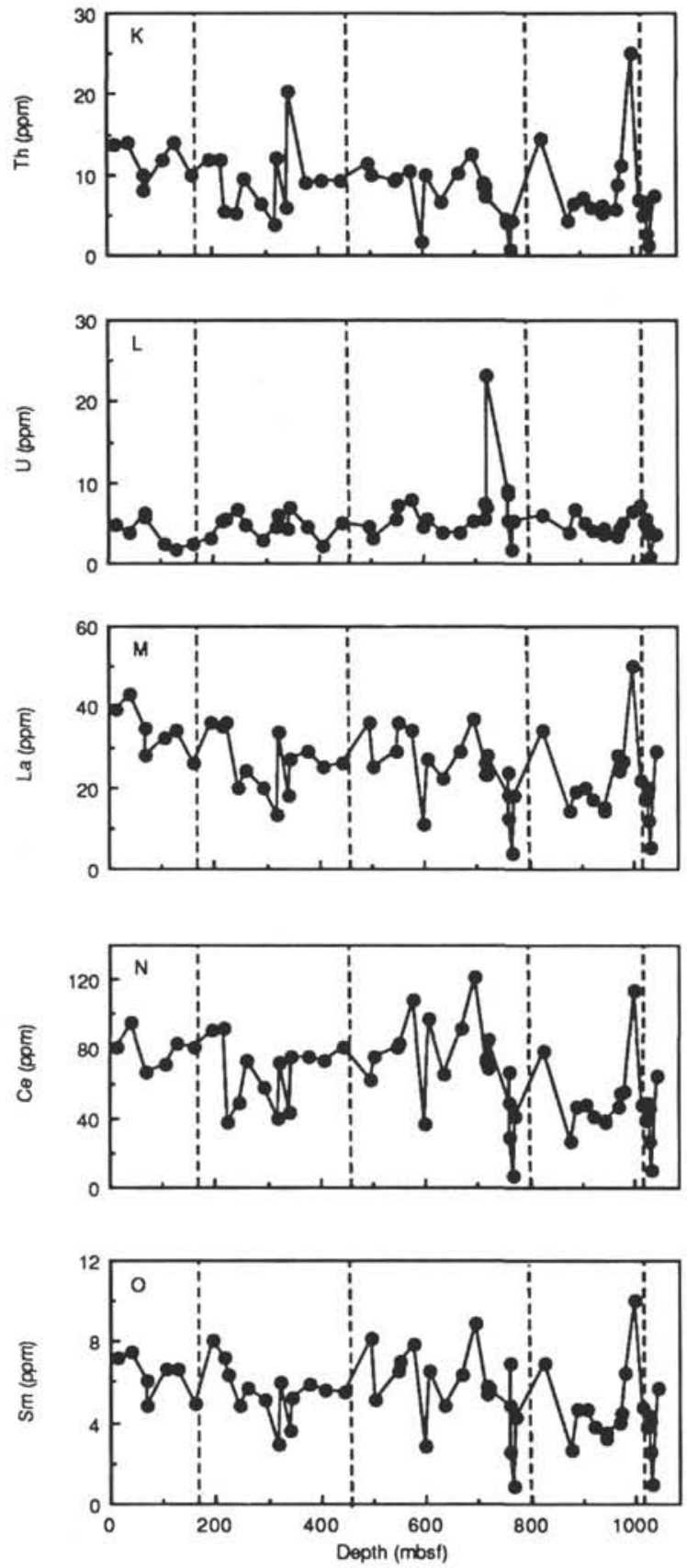

Figure 5 (continued).

sites suggests that diagenetic processes are extremely important in REE geochemistry of marine sediments. Figures $12 \mathrm{C}$ and $13 \mathrm{C}$ show the depth profiles of the Eu/Eu* ratios in the sediments from Sites 798 and 799 , respectively. It has been reported that $\mathrm{Eu} / \mathrm{Eu}^{*}$ ratios in crust-derived materials range from 0.6 to 1 depending on formation age of the crust (e.g., McLennan et al., 1990). Most of the Eu/Eu* ratios in the sediments from Sites 798 and 799 are in the range of the $\mathrm{Eu} / \mathrm{Eu} *$ ratio in crust-derived materials. Terrigenous detritus derived from the continental crust on the Eurasia Plate and the younger crust of the island-arc (partly having a continental-type crust) have been deposited to form the sediments of the Japan Sea. Variation of the $\mathrm{Eu} / \mathrm{Eu}$ * ratio may be interpreted as variation of mixing ratios among various types of terrigenous detritus around the Japan Sea through the geological periods. It should be mentioned that the $\mathrm{Eu} / \mathrm{Eu}^{*}$ ratio in some samples is lower than 0.6 . The Eu/Eu* ratio in sample 51,
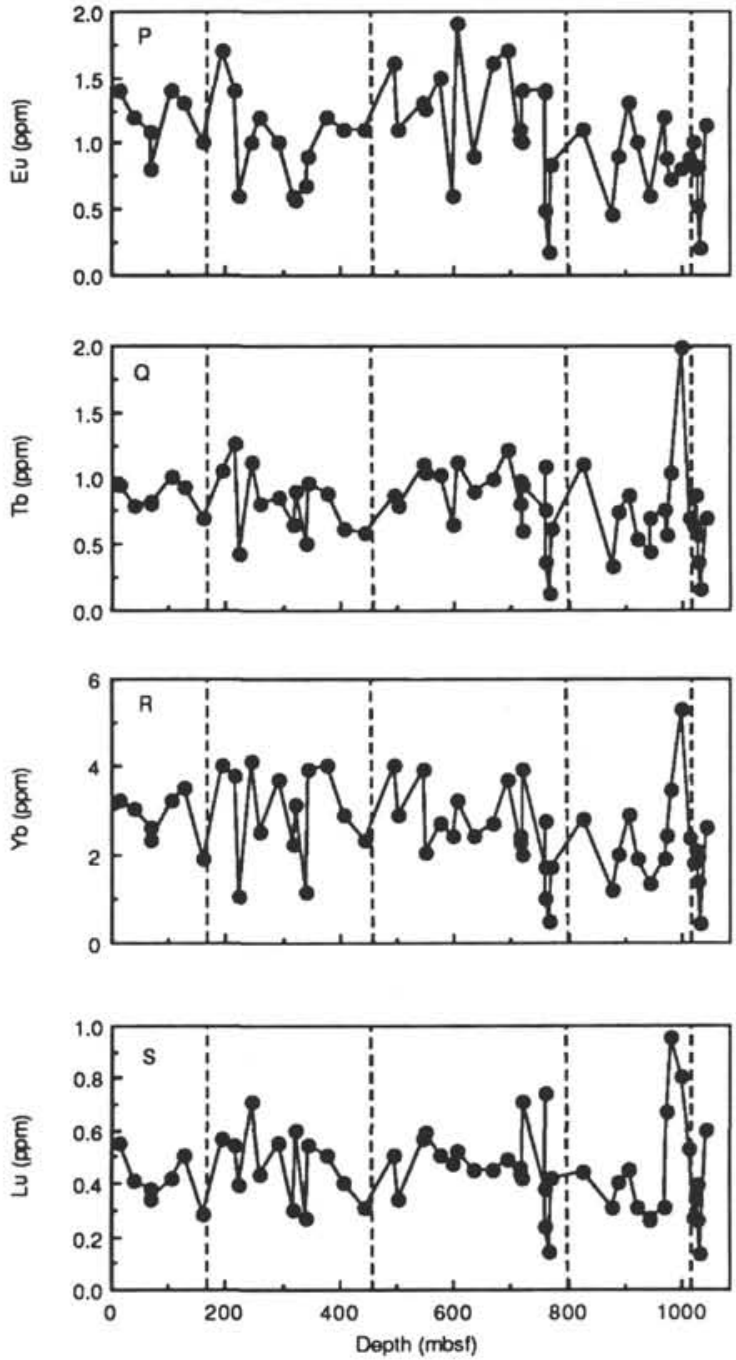

containing rhyolitic volcanic ash, is the lowest among the samples analyzed. Plagioclase fractionation in the formation of rhyolitic magma can lead to selective depletion of europium (negative europium anomaly). Extreme depletion of europium in some sediments may indicate sedimentation of rhyolitic volcanic ash. Perhaps the depth profile of the Eu/Eu* ratio traces changes in rhyolitic volcanic activity and mixing proportions among multiple terrigenous sources in the sediment column.

\section{CONCLUSIONS}

We conclude the following. (1) A positive cerium anomaly may be a measure of hydrogenous precipitation, although it does not correlate with $\mathrm{MnO}$ content, which is sometimes regarded as a measure of hydrogenous precipitation. (2) Correlation between $\mathrm{La} / \mathrm{Yb}$ and 


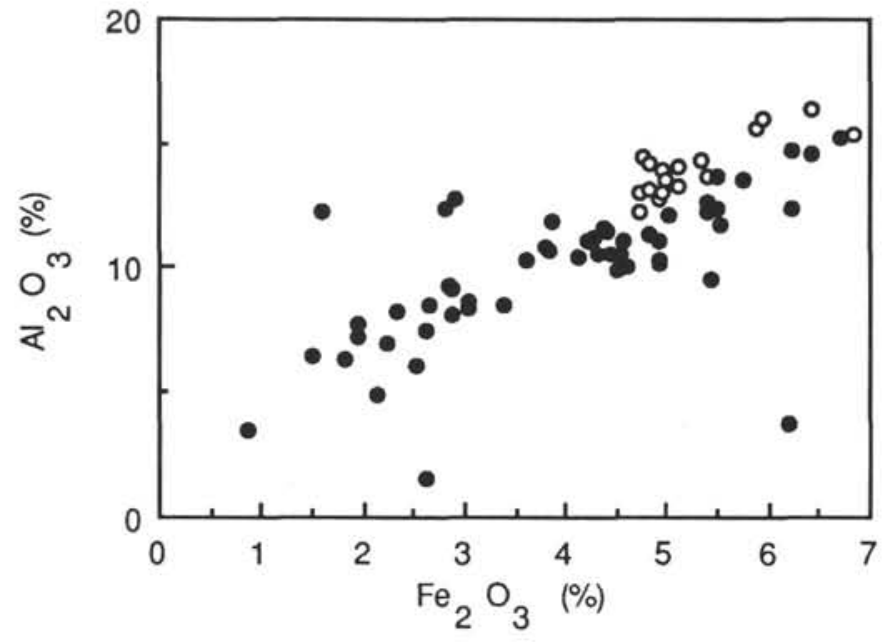

Figure 6. Correlation between $\mathrm{Fe}_{2} \mathrm{O}_{3}$ (total iron) and $\mathrm{Al}_{2} \mathrm{O}_{3}$ contents (\%) in the sediments from Sites 798 (circles) and 799 (dots).

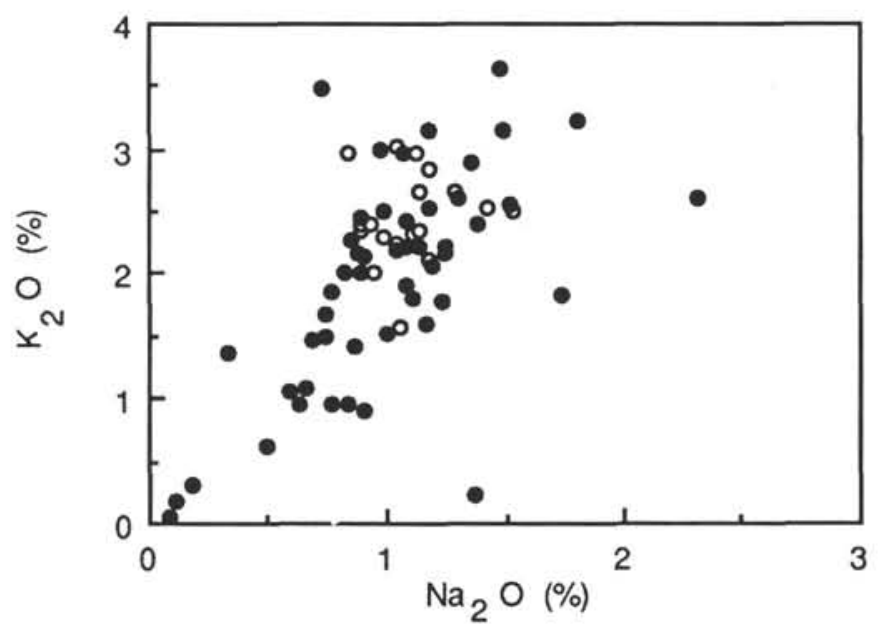

Figure 7. Correlation between $\mathrm{Na}_{2} \mathrm{O}$ and $\mathrm{K}_{2} \mathrm{O}$ contents (\%) in the sediments from Sites 798 (circles) and 799 (dots).

$\mathrm{MnO} / \mathrm{Al}_{2} \mathrm{O}_{3}$ ratios, together with the correlations of $\mathrm{La}$ and $\mathrm{Yb}$ concentrations to $\mathrm{Al}_{2} \mathrm{O}_{3}$ content, may suggest migration of HREE through the sediment column. It also shows that diagenesis is important in the REE geochemistry of marine sediments. (3) Depth profiling of the europium anomaly may indicate variations of rhyolitic volcanic activities and terrigenous sources throughout the sedimentation. (4) The depth profile of the $\mathrm{Th} / \mathrm{Sc}$ ratio is an indicator of variation in basic volcanic activities in the sedimentation. (5) REE pattern and correlation of REE's with other elements suggest that terrigenous detritus is a major source of REE in the sediments. (6) Several major and trace elements (e.g., chromium) are concluded to mainly derive from terrigenous materials.

\section{ACKNOWLEDGMENTS}

The authors thank Prof. H. Wakita of the University of Tokyo for the use of his laboratory for INAA. The authors also thank Ms. I. Kusudo of Science University of Tokyo for her devoted contribution to sample preparation. This research was partly supported by the Inter-University Joint Research Program for Use of the Rikkyo Research Reactor.

\section{REFERENCES}

Ando, A., Kamioka, H., Terashima, S., and Itoh, S., 1989. 1988 values for GSJ rock reference samples, "Igneous rock series." Geochem. J., 23:143-148.

Bender, M., Broecker, W., Gornitz, V., Middel, U., Kay, R., Sun, S.-S., and Biscaye, P., 1971. Geochemistry of three cores from the East Pacific Rise. Earth Planet. Sci. Lett., 12:425-433.

Byrne, R. H., and Kim, K.-H., 1990. Rare earth element scavenging in seawater. Geochim. Cosmochim. Acta, 54:2645-2656.

Cantrell, K. J., and Byrne, R. H., 1987. Rare earth element complexation by carbonate and oxalate ions. Geochim. Cosmochim. Acta, 51:597-605.

Ebihara, M., Minai, Y., Kubo, M. K., Tominaga, T., Aoki, N., Nikko, T., Sakamoto, K., and Ando, A., 1985. Revaluation of lanthanide abundances in Japanese standard rock samples, JG-1 and JB-1. Anal. Sci., 1:209-213.

Elderfield, H., and Sholkovitz, E. R., 1987. Rare earth elements in the pore waters of reducing nearshore sediments. Earth Planet. Sci. Lett., 82:280-288.

German, C. R., and Elderfield, H., 1989. Rare earth elements in Saanich Inlet, British Columbia, a seasonally anoxic basin. Geochim. Cosmochim. Acta, 53:2561-2571.

, 1990. Rare earth elements in the NW Indian Ocean. Geochim. Cosmochim. Acta, 54:1929-1940.

Goldberg, E. D., and Arrhenius, G.O.S., 1958. Geochemistry of Pacific pelagic sediments. Geochim. Cosmochim. Acta, 13:153-212.

Hart, S. R., 1969. K, Rb, Cs contents and K/Rb, K/Cs ratios of fresh and altered submarine basalts. Earth Planet. Sci. Lett., 6:295-303.

Hart, S. R., and Staudigel, H., 1982. The control of alkalies and uranium in seawater by ocean crust alteration. Earth Planet. Sci. Lett., 58:202-212.

Henderson, H. (Ed.), 1984. Rare Earth Element Geochemistry: Amsterdam (Elsevier).

Ingle, J. C., Jr., Suyehiro, K., von Breymann, M. T., et al., 1990. Proc. ODP, Init. Repts., 128: College Station, TX (Ocean Drilling Program).

Karig, D. E., Ingle, J. C., Jr., et al., 1975. Init. Repts. DSDP, 31: Washington (U.S. Govt. Printing Office).

Leinen, M., 1977. A normative calculation technique for determining opal in deep-sea sediments. Geochim. Cosmochim. Acta, 41:671-676.

Masuda, A., Nakamura, N., and Tanaka, T., 1973. Fine structures of mutually normalized rare-earth patterns of chondrites. Geochim. Cosmochim. Acta, 37:239-248.

Masuzawa, T., 1987. Early diagenesis in deep-sea sediments of the Japan Sea: type, controlling factor, and diffusion flux. J. Earth Sci., Nagoya Univ., 35:249-267.

Masuzawa, T., and Koyama, M., 1989. Settling particles with positive Ce anomalies from the Japan Sea. Geophys. Res. Lett., 16:503-506.

Matsumoto, R., and Minai, Y., 1985. Genetical classification of deep sea sediments on the basis of Mn content and REE pattern. J. Sediment. Soc. Jpn., 21:1-9.

Matsumoto, R., Minai, Y., and Iijima, A., 1985. Manganese content, cerium anomaly, and rate of sedimentation as aids in the characterization and classification of deep-sea sediments. In Nasu, N., Kobayashi, K., Uyeda, S., Kushiro, I., and Kagami, H. (Eds.) Formation of Active Ocean Margins: Tokyo (Terra Scientific), 913-939.

Matsumoto, R., Minai, Y., and Okamura, M., 1988. Geochemistry and deposition environments of bedded chert of the Cretaceous Shimanto group, Shikoku, southwest Japan. Mod. Geol., 12:197-224.

McLennan, S. M., Taylor, S. R., McCulloch, M. T., and Maynard, J. B., 1990. Geochemical and Nd-Sr isotopic composition of deep-sea turbidites: crustal evolution and plate tectonic associations. Geochim. Cosmochim. Acta, 54:2015-2050.

Minai, Y., 1982. Geochemical studies of the ocean floor rocks and sediments [Doctoral dissert.]. Univ. of Tokyo.

Minai, Y., Matsumoto, R., and Tominaga, T., 1985. Geochemistry of the deep sea sediments from the Nankai Trough, the Japan Trench, and adjacent regions. In Kagami, H., Karig, D. E., and Coulbourn, W. C., et al., Init. Repts. DSDP, 87: Washington (U.S. Govt. Printing Office), 643-657.

Minai, Y., and Tominaga, T., 1989. Neutron activation analysis of rare earth elements in deep sea sediments from the Pacific Ocean and the Japan Sea. J. Radioanal. Nucl. Chem., 137:351-363.

Murray, R. W., Buchholtz ten Brink, M. R., Jones, D. L., Gerlach, D. C., and Russ, G. P., III, 1990. Rare earth elements as indicators of different marine depositional environments in chert and shale. Geology, 18:268-271.

Piper, D., 1974. Rare earth elements in the sedimentary cycle: a summary. Chem. Geol., 19:285-304. 
Shimizu, H., and Masuda, A., 1977. Cerium in chert as an indicator of marine environment of its formation. Nature, 266:346-348.

Tamaki, K., 1988. Geological structure of the Japan Sea and its implications. Chishitsu Chosasho Geppo, 39:269-365.

Taylor, S. R., and McLennan, S. M., 1985. The Continental Crust: Its Composition and Evolution: Oxford (Blackwell).

Toyoda, K., and Masuda, A., 1990. Sedimentary environments and chemical composition of Pacific pelagic sediments. Chem. Geol., 88:127-141.

Toyoda, K., Nakamura, Y., and Masuda, A., 1990. Rare earth elements of Pacific pelagic sediments. Geochim. Cosmochim. Acta, 52:1557-1569. von Breymann, M. T., Emeis, K.-C., and Camerlenghi, A., 1990. Geochemistry of sediments from the Peru upwelling area: results from Sites 680,682 , 685, and 688. In Suess, E., von Huene, R., et al., Proc. ODP, Sci. Results, 112: College Station, TX (Ocean Drilling Program), 491-503.

Date of initial receipt: 18 March 1991

Date of acceptance: 11 September 1991

Ms 127/128B-180

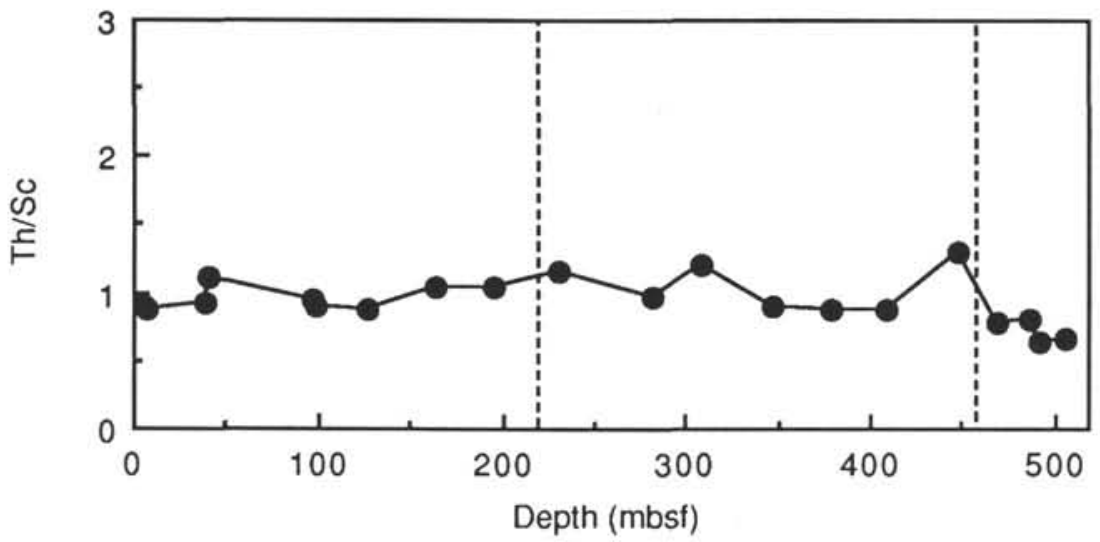

Figure 8. Depth profile of Th/Sc ratio of the sediments from Site 798. Broken lines indicate boundaries between lithological units.

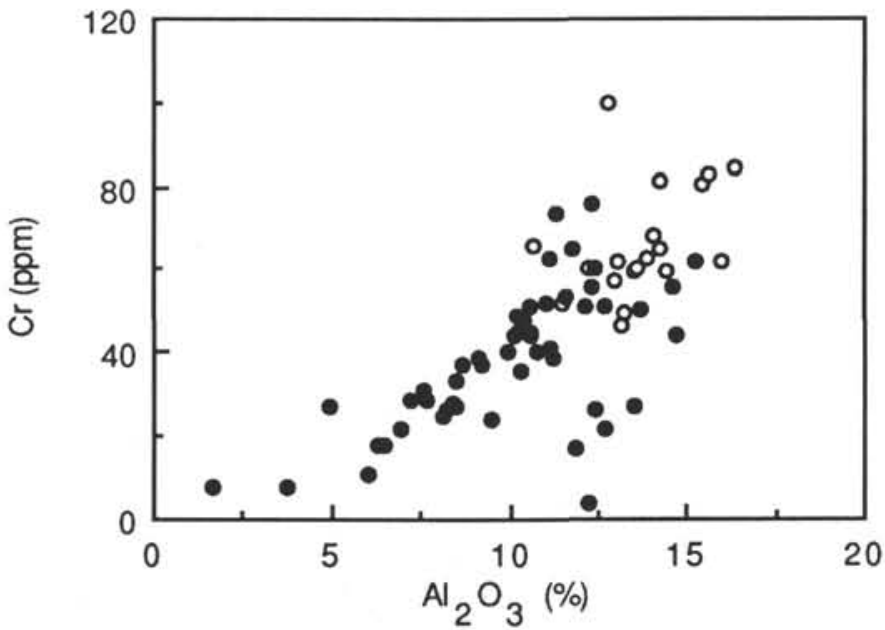

Figure 9. Correlation between $\mathrm{Cr}$ concentration (ppm) and $\mathrm{Al}_{2} \mathrm{O}_{3}$ content $(\%)$ in the sediments from Sites 798 (circles) and 799 (dots). 


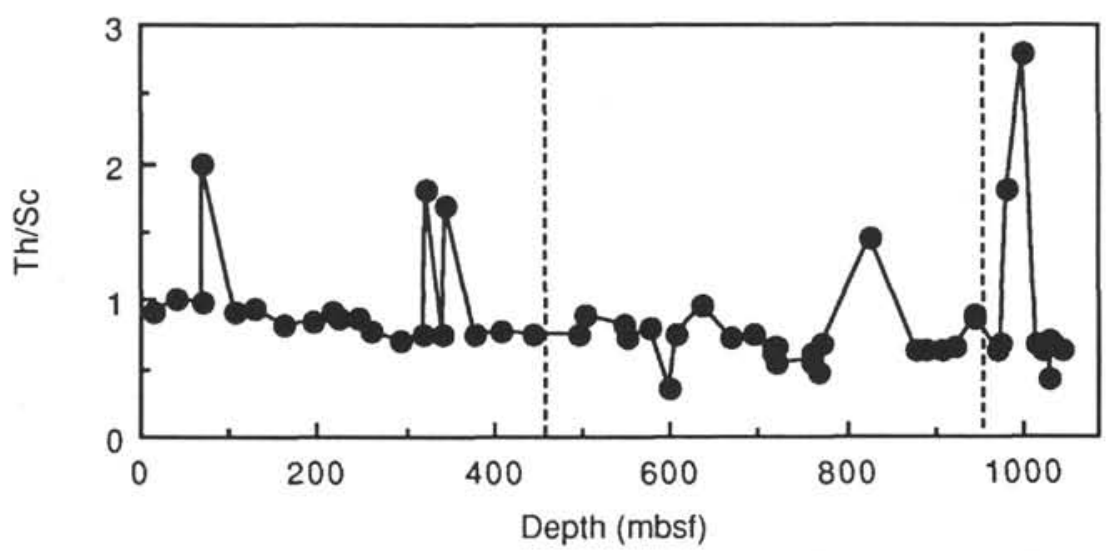

Figure 10. Depth profile of Th/Sc ratio in the sediments from Site 799. Broken lines indicate boundaries between lithological units.
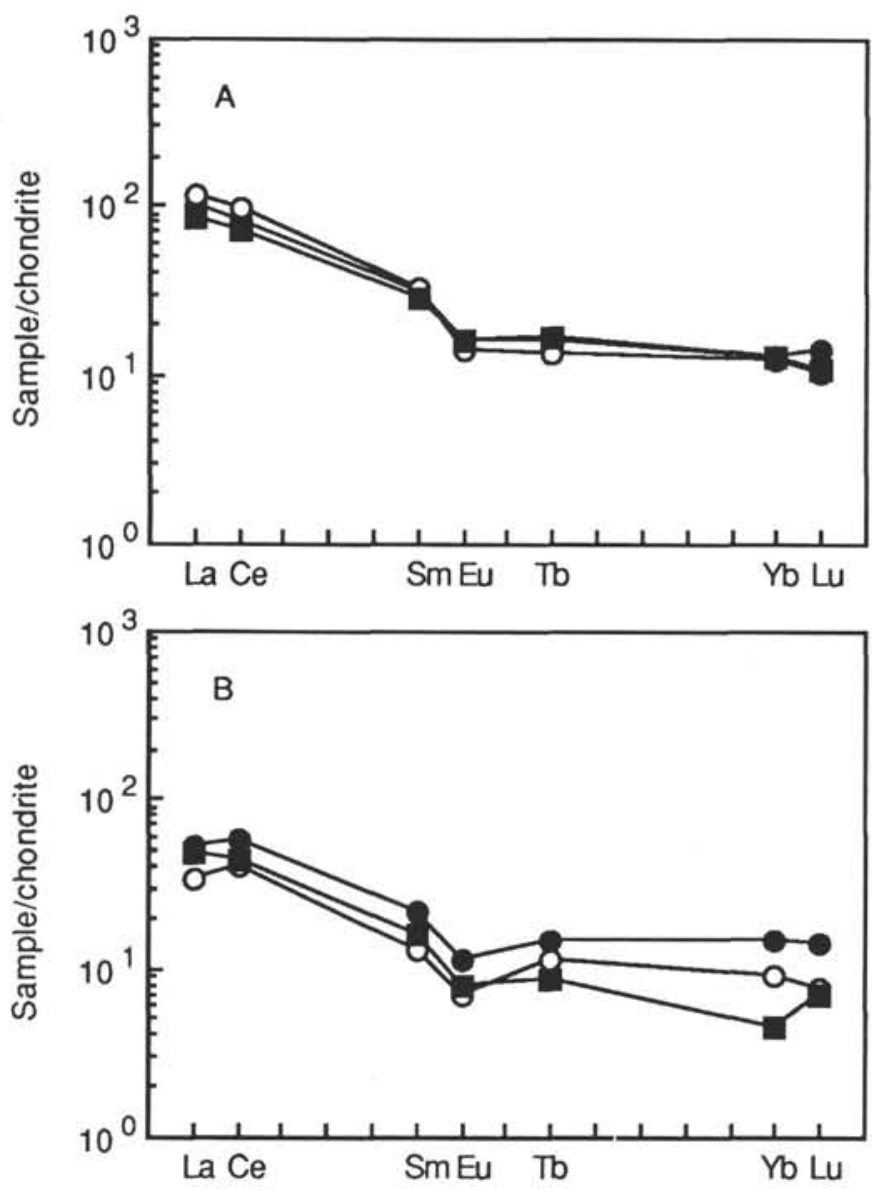

Figure 11. Typical REE patterns (chondrite-normalized) of the sediments from Site 799: A. Quaternary sediment samples 1 (dot), 2 (circle), and 5 (inverted triangle and solid square). B. Pliocene sediment samples 13 (dot), 14 (circle), and 16 (solid square). 

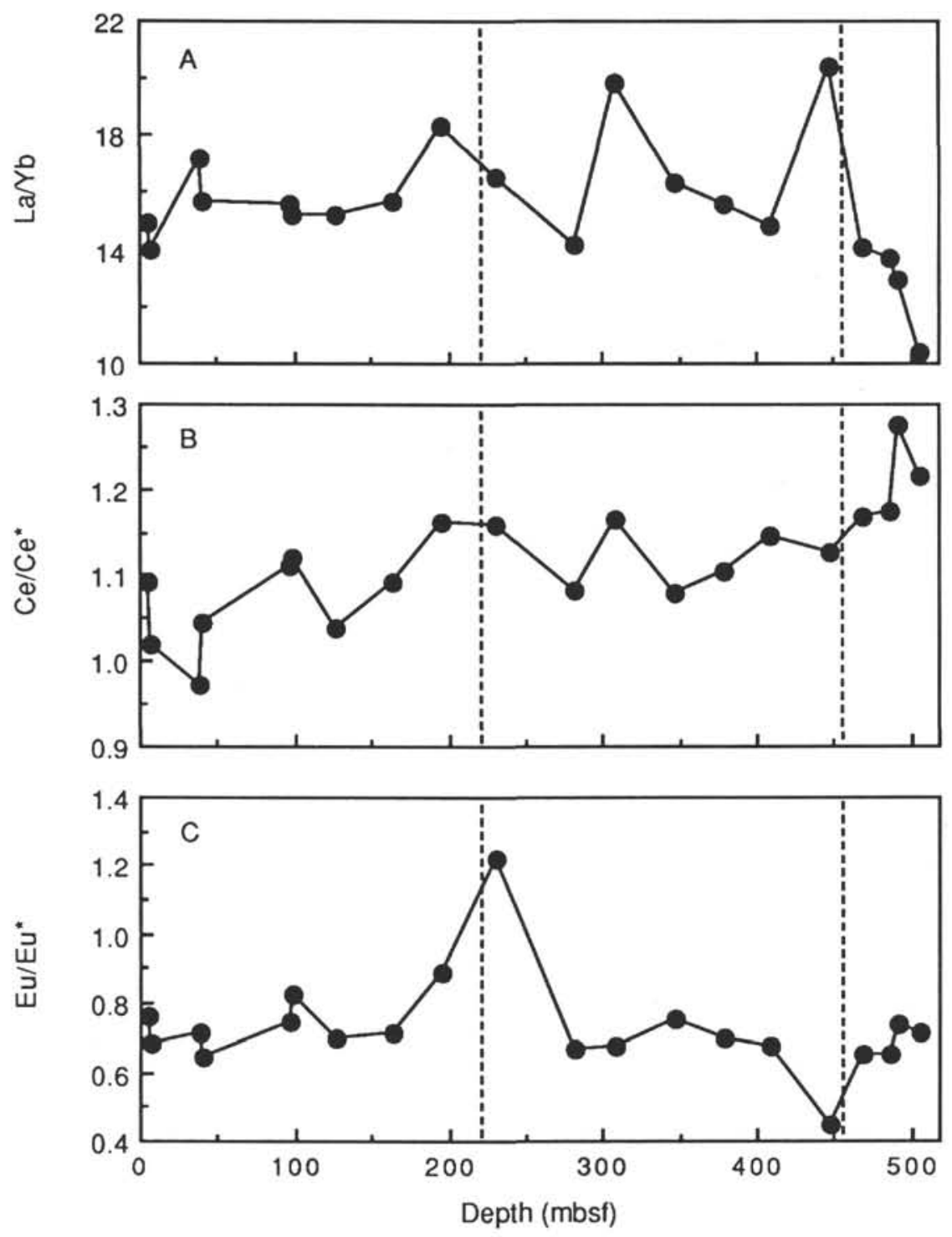

Figure 12. Depth profiles of $\mathrm{La} / \mathrm{Yb}(\mathbf{A}), \mathrm{Ce} / \mathrm{Ce} *(\mathbf{B})$, and $\mathrm{Eu} / \mathrm{Eu}^{*}(\mathbf{C})$ ratios of the sediments from Site 798. Broken lines indicate boundaries between lithological units. 

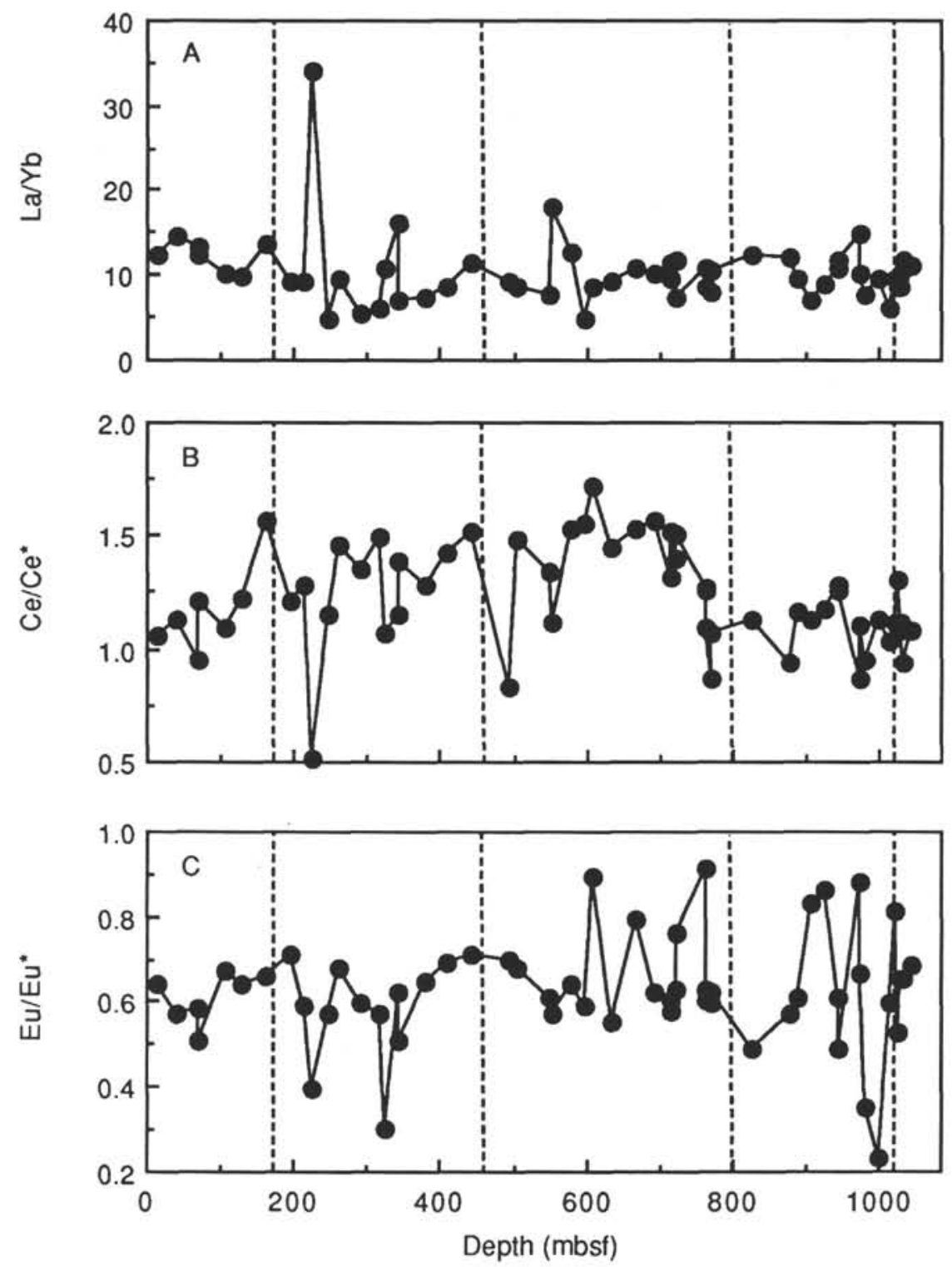

Figure 13. Depth profiles of $\mathrm{La} / \mathrm{Yb}(\mathbf{A}), \mathrm{Ce} / \mathrm{Ce} *(\mathbf{B})$, and $\mathrm{Eu} / \mathrm{Eu}^{*}$ (C) ratios of the sediments from Site 799. Broken lines indicate boundaries between lithological units. 


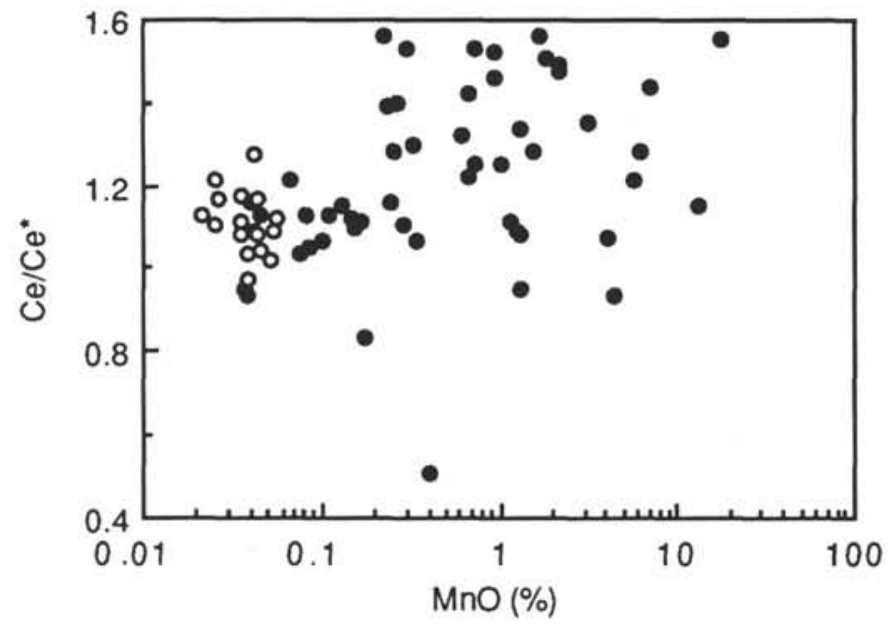

Figure 14. Dependence of $\mathrm{Ce} / \mathrm{Ce} *$ ratio on $\mathrm{MnO}$ content $(\%)$ in the sediments from Sites 798 (circles) and 799 (dots).
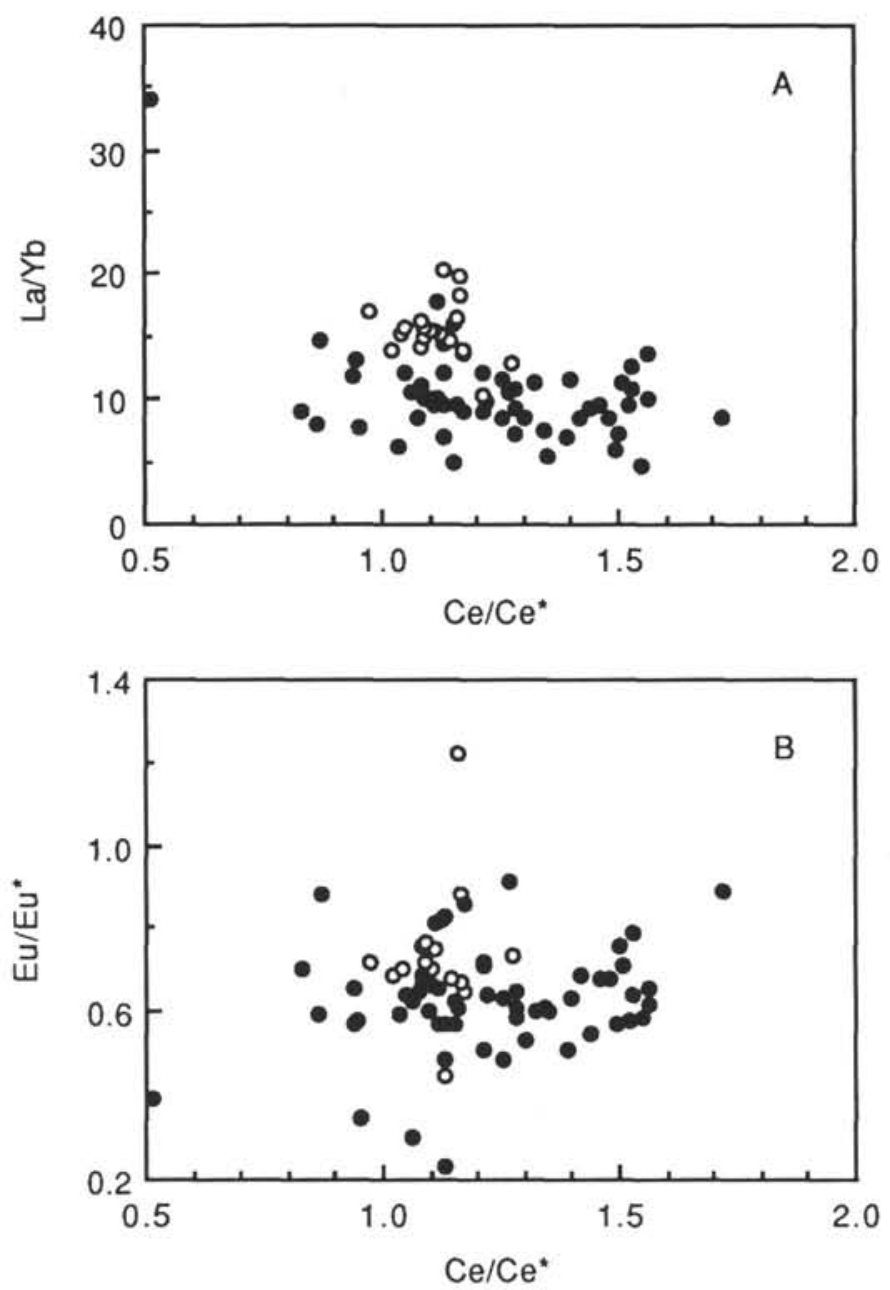

Figure 15. Dependence of $\mathrm{La} / \mathrm{Yb}(\mathrm{A})$ and $\mathrm{Eu} / \mathrm{Eu} *(\mathbf{B})$ ratios on $\mathrm{Ce} / \mathrm{Ce} *$ ratio of the sediments from Sites 798 (circles) and 799 (dots).

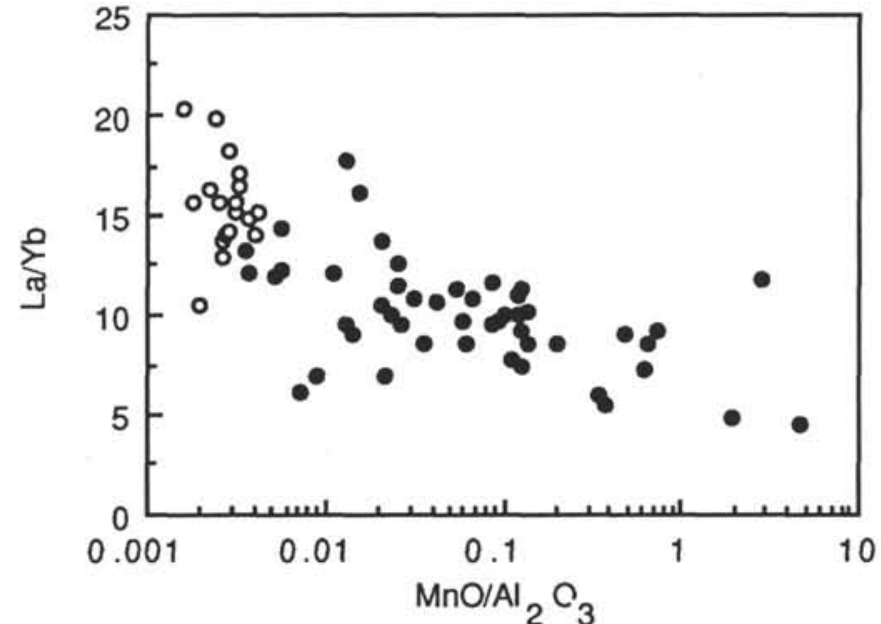

Figure 16. Dependence of $\mathrm{La} / \mathrm{Yb}$ ratio on $\mathrm{MnO} / \mathrm{Al}_{2} \mathrm{O}_{3}$ ratio in the sediments from Sites 798 (circles) and 799 (dots).
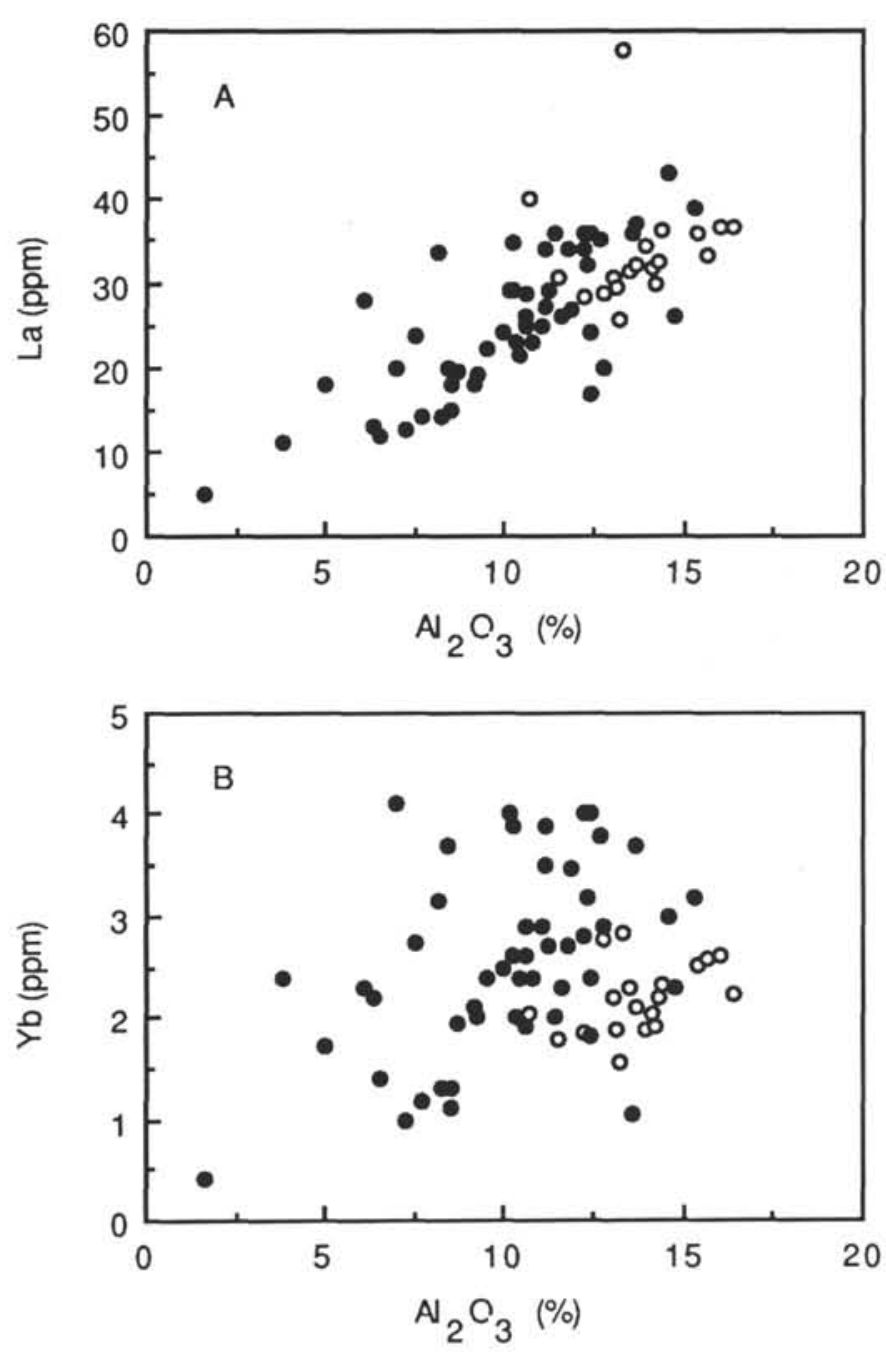

Figure 17. Dependence of $\mathrm{La}(\mathrm{A})$ and $\mathrm{Yb}(\mathrm{B})$ concentrations (ppm) on $\mathrm{Al}_{2} \mathrm{O}_{3}$ content $(\%)$ in the sediments from Sites 798 (circles) and 799 (dots). 